\title{
Broken Worlds: Towards an Archaeology of the Shatter Zone
}

\author{
Ben Raffield ${ }^{1}$ \\ Accepted: 18 March 2021/ Published online: 13 April 2021 \\ (C) The Author(s) 2021
}

\begin{abstract}
In recent years, archaeological studies of long-term change and transformation in the human past have often been dominated by the discussion of dichotomous processes of 'collapse' and 'resilience'. These discussions are frequently framed in relatively narrow terms dictated by specialist interests that place an emphasis on the role of single 'trigger' factors as motors for historic change. In order to address this issue, in this article I propose that the study of the 'shatter zone'-a term with origins in physical geography and geopolitics that has been more recently harnessed in anthropological research - has the potential to facilitate multi-scalar, interdisciplinary analyses of the ways in which major historical changes unfold across both space and time, at local, regional, and inter-regional levels. This article unpacks the concept of the shatter zone and aligns this with existing archaeological frameworks for the study of long-term adaptive change. I then situate these arguments within the context of recent studies of colonial interaction and conflict in the Eastern Woodlands of North America during the sixteenth to eighteenth century. The study demonstrates how a more regulated approach to the shatter zone has the potential to yield new insights on the ways in which populations mitigate and react to instability and change while also facilitating comparative studies of these processes on a broader, global scale.
\end{abstract}

Keywords Shatter zone $\cdot$ Collapse $\cdot$ Resilience $\cdot$ Instability $\cdot$ Colonial interaction $\cdot$ Cultural change Conflict

\section{Introduction}

For millennia, the development of human societies has been characterized by cycles of socio-political growth and change. Archaeologists and historians have devoted

Ben Raffield

Ben.raffield@arkeologi.uu.se

1 Department of Archaeology and Ancient History, Uppsala University, Box 626, 75126 Uppsala, Sweden 
considerable time to studying these processes, especially at points where they intersect with narratives of decline or collapse among complex polities and states. Indeed, it is no exaggeration to say that our very understanding of the human past is often framed by these events, which have long provided a convenient framework for historical periodization. Even today, provocative 'collapse narratives' continue to capture the attention of both scholars and the public alike (e.g. Diamond, 2005; Gill, 2000; Tainter, 1988; Weiss, 2017; Yoffee \& Cowgill, 1988). In the last 30 years, however, there has been a growing recognition that episodes of so-called collapse are very rarely terminal. Rather, these are now regarded as formative periods during which the structures and institutions that underpin society are reformed in order to provide the foundation for a new cycle of growth and development (Clayton, 2016; Faulseit, 2016a; Ferguson \& Whitehead, 1992; Marcus, 1993, 1998, 2012; McAnany \& Yoffee, 2010; Middleton, 2012, 2017; Schwartz \& Nichols, 2006).

In the last decade, scholars have devoted increasing time to studying the factors and conditions that have the potential to generate instability at local, regional, and interregional levels, in addition to the ways in which crises develop and metastasize through time. In many cases, however, this work is framed in narrow terms defined by subjectspecific interests (such as historical ecology and colonial studies), which tend to emphasize the role of specific 'causes' or 'triggers' as motors for historic change. There is a need to establish more holistic frameworks for the study of socio-political and cultural transformation and to consider how these processes impact the lives of communities in both short- and long-term perspective. It is also necessary to adopt a clear-eyed view of what they actually entail. While recent work in resilience studies, for example, has emphasized the formative role that periods of instability play in providing populations with opportunities for innovation (see, e.g. Erickson, 1999; Faulseit, 2016a; McAnany \& Yoffee, 2010: 10-11; Nelson et al., 2006; Weiberg \& Finné, 2013:117), it is important to acknowledge the uncomfortable truth that these are also often characterized by the destruction of social structures, institutions and networks, and indeed human lives (Blackhawk, 2006). While societies might not always 'collapse' under such pressures, many groups will nevertheless be impacted in deeply negative ways (Ethridge, 2020; Izdebski et al., 2018). Rather than perpetuate dichotomous notions of collapse and resilience that emphasize the 'positive' or 'negative' outcomes of these developments, we must instead develop a more realistic perspective on the ways in which periods of instability and upheaval impact populations, as well as the full range of ways in which communities respond to challenges, threats, and opportunities. This is of particular relevance in a time when our own societies are facing significant disruption as a result of global insecurity, the over-exploitation of natural resources, and climate change.

In an effort to address these issues, in this article I will present a preliminary framework intended to support comparative, multi-proxy studies of upheaval and long-term cultural transformation during the past. The study will mobilize the concept of the 'shatter zone', a term first used in the study of physical geography but which for over a century has been applied by geopoliticians, historians, and anthropologists to regions experiencing instability and turmoil. I will begin by briefly tracing the origins and use of this term in academic literature, before redefining it within the context of the current study. The concept of the shatter zone will then be contextualized and aligned with existing models, drawn from resilience studies, which have been mobilised as a 
means of delineating and exploring processes of adaptive change in historic contexts. Drawing on previous archaeological and historical research, I then apply these models to a case study of colonial-Indigenous interaction and social transformation in North America during the sixteenth to eighteenth centuries. Having considered some of the ways in which shatter zones might be identified in the archaeological record, I will outline several potential avenues for future research before offering some final remarks.

Before continuing, a note on the terminology used herein. While the subject of 'collapse', as noted above, has long been a topic of interest in archaeological debate, I will avoid using this term so as to avoid cultivating dichotomous perspectives on 'pre-' and 'post-collapse' societies that portray the latter as somehow culturally inferior to their predecessors (see discussion in Weiberg, 2012). Where possible, the study will prioritize the use of the terms 'upheaval', 'change', and 'transformation'-with full recognition of their ambiguity - as a means of describing the ways in the lives of communities are impacted during times of instability and crisis.

\section{The Concept of the Shatter Zone: Definition and Application}

The concept of the shatter zone has a long history of use across several academic disciplines. The expression 'shatter zone' and its synonymous term 'shatter belt' have their origins in nineteenth- and early-twentieth-century geographical literature, being used to describe a geological fault line or more specifically, a 'belt of broken rock, produced by horizontal movement in a more or less vertical plane' (Morley Davies, 1907: 42). During the early twentieth century, the term was transplanted into the study of geopolitics, a branch of human geography concerned with studying 'the relation of international political power to the geographical setting' (Cohen, 1963: 24). ${ }^{1}$ The terms 'shatter belt' and 'shatter zone' were used to describe politically unstable regions or immature states, often located between two or more major global powers, which were considered to hold a strategic role in the expansion and consolidation of imperial rule (see, e.g. Cohen, 2005; East, 1961: 14; Hartshorne, 1941; Hensel \& Diehl, 1994: 33-9; Hoffman, 1952: 25; Mahan, 1900; Mackinder, 1904, 1919). Most recently, Saul Bernard Cohen (2015: 57) has defined shatter zones as 'strategically oriented regions that are both deeply divided internally and caught up in the competition between Great Powers of the geostrategic realms'. In geopolitical discussions shatter zones are almost universally portrayed as 'backwards and fragmented regions' of negligible international influence (Reilly, 2000:49). Indeed, consideration of these regions often focuses almost wholly on their potential to disrupt global security and, more specifically, the geostrategic designs of certain states (Cohen, 2015; Fox, 1985; Hensel \& Diehl, 1994; Reilly, 2000). As noted by Danilovic (2002: 106), the concept is generally deployed as a descriptive tool to discuss what is by Western standards a political 'anomaly'.

Since the Second World War, the concept of the shatter zone has been applied in studies of modern history and historical geography, most often in relation to Eastern Europe (see, e.g. Bugge, 2002; Bartov \& Weitz, 2013). It has also found use-with some modification — in anthropology (for a summary see Jeter, 2009: 380). The 'shatter zone' is a dynamic concept that has significant application to anthropological and

\footnotetext{
${ }^{1}$ For a concise discussion of shatter zone theory in geopolitics, see Hensel and Diehl (1994).
} 
archaeological research; it can be used not only to identify and delineate a specific geographical region of interest but also to capture the nature of the developments taking place within it. It allows an equal weight to be placed on the study of environment and historical processes and for these to be charted across space, time, and social strata (White, 1991).

Early anthropological discussions of shatter zones drew on perspectives that had previously been offered in geopolitical discourse. They were generally portrayed as peripheral or remote, rugged, and politically decentralized regions, often occupied by numerous autonomous states and tribal groups displaying high levels of ethnic and cultural diversity (see Arlinghaus, 1988: 6-7; Cohn, 1967: 12). Since the 1990s, however, historical and anthropological discussions of shatter zones have become deeply entangled with the study of early modern colonial interaction (see White, 1991; Wolf, 1997). The concept has been most comprehensively dealt with by Robbie Ethridge, who harnesses this as a means of studying cultural contact and commercial interaction between Native American communities and Europeans in colonial North America. In documenting the impacts of this interaction, Ethridge (2006: 208) argued that the arrival of foreign traders and colonists from the sixteenth century, coupled with 'the inauguration of commercial trade and its attendant colonial struggles', led to a selffuelling spiral of upheaval and violence that resulted in the formation of what is now called the 'Mississippian shatter zone'. As part of this work, Ethridge (2006: 208) defined shatter zones as 'large regions of instability from which shock waves radiate out for sometimes hundreds and hundreds of miles.' Drawing on Ferguson and Whitehead's (1992: 3) concept of the 'tribal zone', Ethridge argued that the shattering of traditional lifeways among Indigenous communities led to a process of 'tribalization', and the emergence of coalescent societies whose socio-political structures and cultural traditions both drew upon and diverged from those of the pre-contact period. Aligning the concepts of the shatter and tribal zones in this way has allowed Ethridge and others to expound upon the upheaval and trauma associated with the shatter zone while also highlighting the resilience of Indigenous communities (see, e.g. Ethridge \& Hudson, 1998; Hudson, 2002; Kowalewski, 2006).

The concept of the shatter zone has also found expression in other contexts. Of note is James Scott's (2009) monograph, The Art of Not Being Governed, which has played an influential role in shaping current archaeological discourse on shatter zones. In his thesis, Scott examines the influence of nation states on the development of communities inhabiting the mountainous 'shatter zone' of Zomia, a region known geographically as the Southeast Asian mainland massif. In contrast to Ethridge (2006), Scott sees shatter zones as places where coalescence and cultural integration are actively maintained as a form of resistance against state intrusion. He defines shatter zones as regions of refuge from predatory states-geographically inaccessible and culturally heterogeneous borderlands, where 'the human shards of state formation and rivalry accumulated willy nilly, creating regions of bewildering ethnic and linguistic complexity' (Scott, 2009: 7). This perspective has been adopted by other scholars concerned with studying borderland populations and their relationships with states (see, e.g. Hauser \& Armstrong, 2012; González-Ruibal, 2014; Matthee, 2015).

While Scott's efforts to emphasize the agency and self-determination of shatter zone populations are well-taken, the picture of these regions that emerges from his study is coloured by an infusion of historical and political perspectives that explicitly frames 
these regions as 'twins' of nation states (see, e.g. Scott, 2009: 326). In this, shatter zones do not exist outside of a dichotomous state/non-state context. The perspective offered by Ethridge (2006), in contrast, allows for a measure of adaptability and reflexivity when delineating and studying the emergence of shatter zones in disparate contexts, thereby facilitating the development of approaches that can applied more broadly to the study of the archaeological record.

Given that the concept of the shatter zone has been redefined several times throughout the twentieth and twenty-first centuries, there is a need to clarify the definition of these regions used in this study. While it is important to stress that all of the definitions noted above have something to offer to the archaeological study of shatter zones, that offered by Ethridge (2006: 208) provides the best point of departure for this article. Building on this, shatter zones are defined here as large areas, often extending across multiple geographical, territorial, and political boundaries, which are subject to widespread upheaval and instability that leads to the breakdown and restructuring of sociopolitical order, institutions, and cultural practices. The impacts of these processes have the potential to metastasize in such a way that they spill out into adjoining regions and in doing so to affect the lives of distant communities.

\section{The Emergence of a Shatter Zone: Adaptive Change and Entangled Lifeways}

When described in the broad terms used above, the concept of the shatter zone and the circumstances underpinning their emergence might initially appear simple. Like all major historical changes, however, this process is in fact underpinned by multiple social, political, cultural, and environmental factors, including short-term destabilizing 'triggers' and longer term developments that prime for unfavourable conditions, which combine in a unique way to establish a context for change within a specific place and time (Price, 2020: 272). In an effort to align this concept with the study of the archaeological record, I will now integrate the notion of the shatter zone into two existing models for the study of adaptive change that have been mobilized by scholars working in resilience studies. The aim of this discussion is to highlight the potential to develop a more theoretically oriented approach to the study of shatter zones, which can then be used to establish a baseline for future cross-cultural and comparative studies.

As noted above, archaeologists and anthropologists have long sought to define, contextualize, and study large-scale processes of historic transformation among human societies. Those working within the sphere of 'collapse' and 'resilience' studies have been particularly active in developing models that allow these changes - and the factors that underpin them - to be isolated and analysed in detail. While it is not possible to provide a comprehensive overview of these models here (see instead Cowgill, 2012; Faulseit, 2016b; Middleton, 2012, 2017: 11-48; Schwartz, 2006), one can nevertheless chart a relatively clear evolution from those focusing on monocausal factors for 'collapse' (see e.g. Tainter, 1988) to more complex trajectories of social development (e.g. Flannery, 1972; Renfrew, 1984; Simon, 1965), political cycling (e.g. Adams, 1978; Iannone, 2002; Marcus, 1993, 1998, 2008; Parkinson \& Galaty, 2007; Stark, 2006), and studies of resilience and adaptive change (see, e.g. Bradtmöller et al., 2017; Redman, 2005; Rogers, 2017; Weiberg, 2012). While the efficacy of many earlier 
models is attested by their continuing use, there has been a perceptible shift towards the construction of more inclusive and holistic frameworks that allow numerous, intertwined processes of social transformation to be identified and studied collectively.

Just as many of the models noted above have drawn upon those offered by earlier scholars, the discussion here makes use of two existing frameworks that have been developed as a means of studying resilience and historic change. The first of these is the 'panarchy', an ecological model that has been harnessed by archaeologists seeking to better understand how processes of socio-political and cultural transformation impact the long-term development of social systems (Gunderson \& Holling, 2002; Holling, 1973, 2001; for discussion, see e.g. Bradtmöller et al., 2017; Redman, 2012; Rogers, 2017; Weiberg, 2012). A panarchy is defined by interconnectivity between numerous 'adaptive cycles', which are often visualized as an 'infinity symbol' split into four phases of exploitation, conservation, release, and reorganization. In this case, each of these stages can be taken to represent processes of social growth, stabilization, decline, and reconstruction within human societies. The front loop of the cycle - comprising the processes of exploitation and conservation - is characterized by slowly increasing connectiveness and rigidity within the system. The back loop, in contrast, is defined by rapid change and a breakdown of connectivity that characterizes the processes of release and reorganization (see Fig. 1; also Holling, 2001: 394; Holling \& Gunderson 2002: 33-35).

In outlining the structure of a panarchy, C.S. Holling (2001: 397) uses the analogy of a forest ecosystem. Holling states that we can envisage a panarchy as comprising numerous interconnected adaptive cycles, each of which represents a component of the collective system. The largest cycle, which might represent the forest itself, is connected to and influenced by 'nested' levels of smaller cycles representing stands of trees, an individual tree, and each leaf of that tree (see also Allen et al., 2014; Holling et al., 2002: 68). The cycle of adaptive change begins with the rapid emergence of different forest species, which eventually reach a state of sustainable conservation. While the ecosystem continues to develop, long-term stabilising or 'remember' factors such as climate regulation provide the forest with the means to sustain itself. It may also be exposed, however, to destabilising, short-term 'revolt' conditions that test its resilience at various levels (Holling, 2001: 397). As the system reaches a state of conservation, it becomes increasingly vulnerable to destabilising conditions. In cases where revolt conditions exceed tolerance thresholds, a process of 'creative destruction' is initiated that can rapidly collapse through one or more levels of the ecosystem (Holling, 2001: 395). The decline of the forest environment and the release of nutrients back into the soil over time represents a phase of reorganization that sets the stage for a subsequent sequence of regrowth and development.

If we are to apply the panarchy framework to the study of shatter zones, then societies can be visualized as comprising numerous, nested, and hierarchically linked adaptive cycles. These can extend along various axes (e.g. geographical, cultural, chronological; see Weiberg, 2012:154) and across multiple social and institutional structures (e.g. kinship groups, settlement communities, household organization, and resource (re)distribution systems; see Faulseit, 2016b: 16). Periods of social growth and stability can be sustained only as long as population groups are able to adapt to and resist destabilizing conditions. While long-term social stability is provided by top-down 'remember' factors, which might include socially ingrained behaviours and traditions 


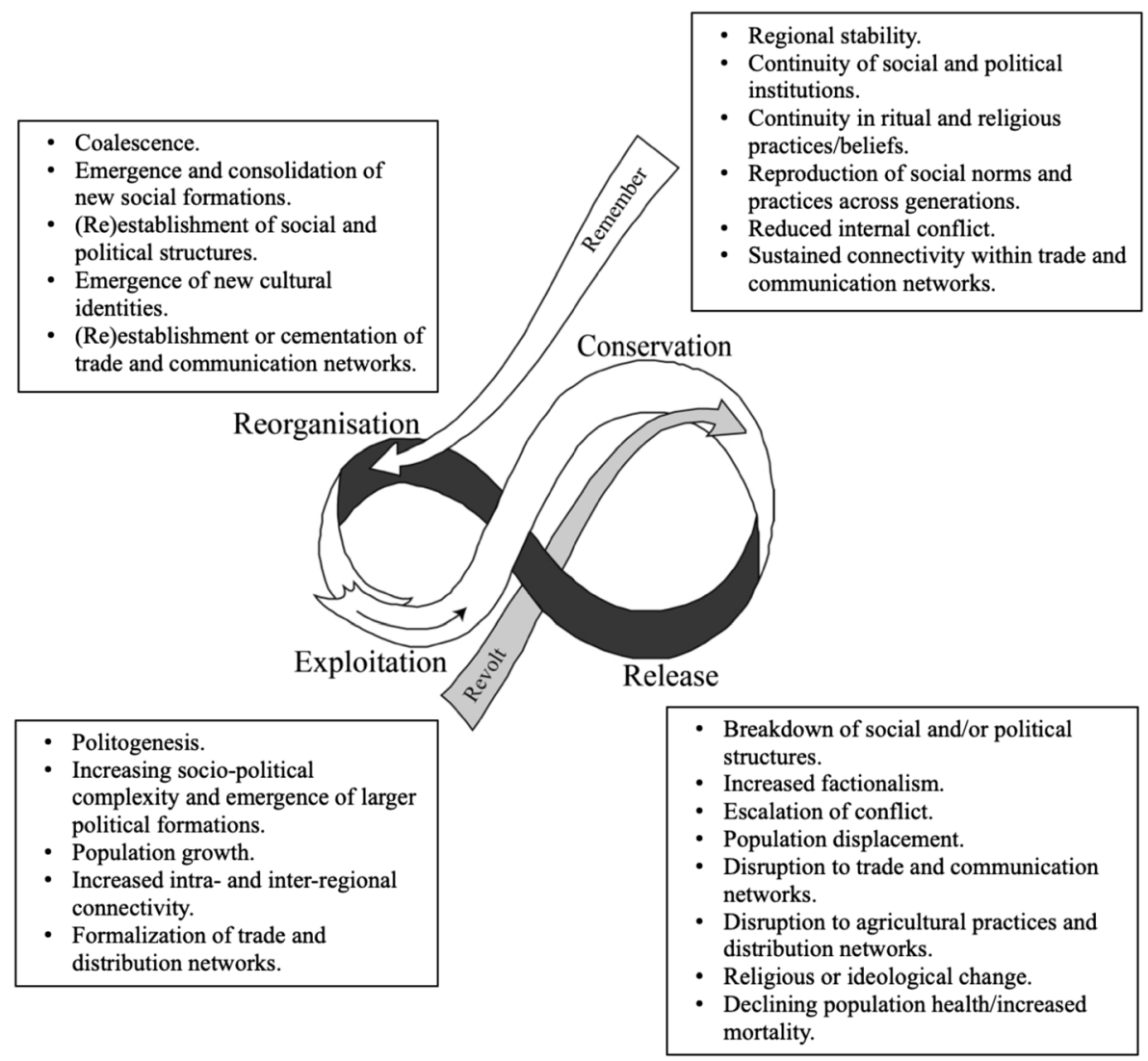

Fig. 1 The adaptive cycle of the panarchy, aligned with examples of conditions that characterize the development of a shatter zone. Note that the examples provided here are neither exhaustive nor universally applicable cross-culturally. Many of these processes, furthermore, may play out across multiple stages of the adaptive cycle. Image adapted from Holling (2001: 398)

or political structures, various 'revolt' conditions (such as conflict or resource scarcity) might simultaneously test the resilience of these institutions. As social, political, and cultural structures become institutionalized, however, so too do these have the potential to become increasingly brittle. When population groups fail to adapt or maintain resilience in the face of changing conditions, they enter into a period of release or 'creative destruction' that is characterized by the fragmentation of social structures and hierarchies, institutions, and lifeways across one or more levels of the social hierarchy (Holling, 2001: 399).

Because the adaptive cycles within a panarchy operate asynchronously, changes taking place locally (e.g. within individual communities) may not always influence broader processes of socio-political transformation within polities or societies. When prevailing conditions prime for movement within multiple adaptive cycles or communities, however, these have the power to act as a collective force that provide a context for large-scale changes at the societal or inter-regional level. The interconnectivity of individual cycles within a panarchy, furthermore, means that even small changes taking place locally can potentially trigger larger scale movements within adaptive cycles if 
conditions are favourable. Temporally, these movements need not take place simultaneously; rather, some communities or regions might initially lag behind others, only to experience their own process of release at a later date. The randomicity of such movements once again highlights the complex intersection of short- and long-term factors that underpin historic change (Saltini Semerari, 2017: 546; Stoddart, 2010; Weiberg, 2012: 149).

With the fragmentation or shattering of lifeways, population groups enter into a period of uncertainty. This is a time when pre-existing norms and institutions may be questioned, adapted, or reconstituted in order to support new daily routines and communal structures. Some groups might, for example, seek to realign or reaffirm social relationships and networks, reorganize centralized distribution networks, or establish new forms of political or ideological control. Crucially, all of these actions will have a significant impact on subsequent phases of social developmental and growth, meaning that new cycles will never directly replicate those which came before. In some cases, cultural memories of previous institutions and lifeways might ensure that new social structures and cultural traditions closely resemble those which had existed previously, differing only in subtle ways. In others, they might re-emerge in a very different or altogether less-complex form (see Holling, 2001: 395, 397; Marcus, 1998: 60).

Over the last two decades, the adaptive cycle has been mobilized as a framework for numerous historical and archaeological studies. Margaret Nelson et al. (2006), for example, have used this to examine changing occupational patterns and household size, configuration, and structure in the eastern Mimbres region of New Mexico during the eleventh to thirteenth centuries CE. More recently, Jakob Sedig (2016) has applied this to the study of social complexity in the American Southwest following the decline of Chaco Canyon during the mid-twelfth century CE. The panarchy framework has also been used more explicitly by Sean Geobey and Katharine McGowan (2019) as a means of examining social resilience during the period of the Black Death in the fourteenth century CE.

When applied to the definition of shatter zones outlined above, the potential application of the panarchy concept becomes readily apparent. If viewed from a topdown perspective, the metaphorical 'shattering' of lifeways that precipitates coalescence and tribalization can be broadly aligned with a transition from the conservation, to release, and subsequent reorganization stages of the adaptive cycle (Holling, 2001: 397). The reconsolidation of communities and lifeways then sets the stage for a new phase of socio-political and cultural development and the return to the process of exploitation or social growth that characterizes the front end of the adaptive cycle (see Fig. 1). While these processes inevitably blend and merge with each other chronologically, the alignment of the shatter zone with the adaptive cycle allows the latter to act as a heuristic tool that facilitates the study of transformation and continuity not only across multiple levels of society but also geographically and diachronically.

A second and more recent model that has particular relevance to the study of shatter zones is 'disentanglement'. Developed by Giulia Saltini Semerari (2017) as a means of conceptualizing the complex, interconnected relationships that underpin the operation of socio-political and economic networks, this concept draws both upon resilience theory and Ian Hodder's (2012) 'entanglement' framework as a means of exploring the ways in which human-thing and human-human relationships intersect with and influence connectivity and continuity within and between communities. 
In outlining her model, Saltini Semerari (2017: 544-48) describes network connectivity as being shaped by interaction at two levels - the 'local' and 'macro' (i.e. regional or inter-regional) levels - each of which represent a mutually influential sphere of contact between groups of actors. Regularized interaction as part of these networks can lead the primary actors within them to become increasingly reliant on the exchange of objects or ideas that uphold long-term order and social continuity. These might, for example, underpin ideals concerning elite power and social hierarchies and in the case of specific objects occupy central places in political economies of redistribution. These relationships, however, are at risk of becoming brittle as the social importance ascribed to them increases. Eventually, this reliance leads to the entanglement of agents and objects - the emergence of a state of mutual dependency that can become upset by any number of internal or external factors. A break in connectivity, incurred for example due to the loss of one or more nodes within a trading or redistribution network, has the potential to instigate a process of disentanglement similar to that which takes place during the release stage of the adaptive cycle (see Hodder, 2012: 119-20; Iannone, 2016: 202; Saltini Semerari, 2017: 548).

This disruption can have significant impacts. As seen within the panarchy framework, relatively small changes taking place among one community have the potential to severely interrupt connectivity within regional and inter-regional networks, with potential knock-on effects that might be amplified elsewhere (Saltini Semerari, 2017: 546). Disruption to political economies that rely on the maintenance of elite-controlled distribution or gift exchange networks, for example, can lead to the unravelling of previously entangled relationships of obligation and dependency that had previously underpinned cooperation and stability among communities (see Gosden, 1999). This increases the potential for the emergence of factionalism as groups are forced to adapt, innovate, or acquire these objects by other means. It can also lead to the fragmentation of socio-political structures and institutions, with actors mitigating for or taking advantage of the situation by developing new strategies and relationships that allow them to maintain or re-establish order (Saltini Semerari, 2017: 563, 569). As seen in the adaptive cycle, this disentanglement precipitates a period of consolidation, involving the reorganization or 're-entanglement' of contacts and connectivity over time. Once-peripheral contacts might become more pronounced, leading to a shift in the acquisition and use of material culture that reflects the establishment of new relationships, with obvious implications for the study of cultural interaction and hybridization (Saltini Semerari, 2017: 551$57,563)$. In other cases, periods of disruption may provide a context for the reestablishment of pre-existing social connections, thereby ensuring a measure of continuity moving into the next phase of social development or growth.

In studying these relationships, archaeologists are able to address key issues that emerge within discussions of social change. Adopting a disentanglement perspective, for example, forces researchers to examine the nature of the networks under consideration (Saltini Semerari, 2017: 568). Which groups within a community or society maintain the most substantial networks of non-local contacts, and how do they benefit from this? How are materials obtained and redistributed by the key players within these networks? How do these groups mitigate for disruption, and what steps do they take to secure their interests when networks become compromised? In establishing 
a context for disentanglement, there is potential to integrate narratives of socio-cultural transformation into longer-term chronological frameworks that provide insights not only into the conditions that underpin change among communities, but also the ways in which relationships are reconfigured following a breakdown of connectivity within networks.

When combined, the panarchy and disentanglement models have significant potential to augment the archaeological study of shatter zones. To date, the concept of the shatter zone has generally been mobilized as a descriptive device - a term used to encapsulate long-term change and transformation taking place within unbounded, unstable geopolitical or cultural landscapes (Ethridge, 2010: 4). Rather than advocating for the use of either a 'top-down' or 'bottom-up' approach to the study of shatter zones, I would argue that researchers need to adopt a multi-focal perspective that accounts for both short- and longer term processes of change manifesting at local, regional, and inter-regional levels. When taken together, the models described above provide a basic framework that facilitates these goals.

Both models incorporate their own strengths and weaknesses. At first glance, the panarchy framework might be perceived as overly-homogenizing when applied at a societal level. Indeed, the motif of an adaptive cycle implies that groups will experience and react similarly to a pre-defined, sequential process of change. The interconnectivity of individual adaptive cycles within the framework, however, does allow for a significant measure of flexibility that can be used to account for non-linear developments. It is possible, for example, to avoid entering into a release phase if the impacts of change can be successfully managed and mitigated. In some cases, this may allow groups to move directly from a stage of conservation to one of exploitation, thus circumventing a potentially catastrophic phase of release (see, e.g. Iannone, 2016: 181; Walker et al., 2006; Torvinen et al., 2016). In this, the adaptive cycles of the panarchy should not be perceived as strictly rigid or recurring - rather, each phase of the cycle is driven by its own unique set of prevailing conditions (see, e.g. Faulseit, 2016b: 13; Hoover \& Hudson, 2016). Because the adaptive cycles within the panarchy operate asynchronously, furthermore, the model allows more rapid changes taking place at a local level (e.g. within individual communities) to be integrated into wider narratives of transformation that play out at a regional or inter-regional scale (Saltini Semerari, 2017: 546-57).

Though less well-defined than the panarchy, the disentanglement model offers an added social dimension to the study of adaptive cycles at a community or polity level. By focusing on the ways in which disentanglement effects actors and their networks, the study of this process allows archaeologists to identify the ways in which instability permeates and disrupts everyday life across social strata (Saltini Semerari, 2017: 546, 548; see also Bintliff, 2007; Stoddart, 2010). The framework therefore lends a greater level of analytical detail than that offered by more systemic models such as the panarchy, which in contrast emphasize a continuous flow of energy through cycles of socio-political development (Faulseit, 2016b: 12-13; also see Hodder, 2012: 108; Legg et al., 2019: 99-100). The harnessing of Hodder's (2012) entanglement framework alongside resilience theory, furthermore, not only emphasizes co-dependency as a natural state in human-human and human-object relationships, but it also accounts for cultural variability and randomicity in the nature of network disruption and human responses to this (Saltini Semerari, 2017: 546). Whereas previous studies have 
described shatter zones as peripheral or marginal regions (e.g. Arlinghaus, 1988; Cohn, 1967; Scott, 2009), the disentanglement framework situates the populations of these regions firmly at the centre of formative processes of socio-cultural change. In this, a shatter zone might be envisaged as a web of entangled communities, objects, and places, each existing with their own fluid, interconnected spheres of social, political, and cultural influence and contact (Iannone, 2016: 184).

Finally, in considering the potential applications of the panarchy and disentanglement models, it is important to emphasize that they should not be seen as rigid or binding. Rather, they are heuristic devices that offer a convenient and expedient means of accounting for large amounts of qualitative data, which can then be interrogated and examined in greater detail (see Iannone, 2016: 181). They are also flexible in their application, with potential to be used either as 'closed' or 'open' models that shed light on the lives of single or multiple population groups. When situated within the context of the shatter zone, they can be used to bind numerous lines of evidence together in such a way that they speak collectively to the experiences of societies undergoing dramatic processes of transformation.

\section{Living in a Broken World: Shatter Zones in Colonial North America}

Having explored the ways in which the formation and development of a shatter zone might be conceptualized, I will now seek to broadly align these models with a historical and archaeological case study for the emergence of two shatter zones in North America during the sixteenth to eighteenth centuries. The first is the so-called Mississippian shatter zone, which emerged within the cultural sphere of the Mississippian chiefdoms during the sixteenth century (for comprehensive discussion, see Ethridge, 2006, 2010; Ethridge \& Shuck-Hall, 2009, among others). The second can be identified in the lands inhabited by Northern Iroquoian peoples in the eastern Great Lakes region (referred to here as Iroquoia) during the seventeenth century. Collectively, therefore, they encompassed a large swathe of the area referred to by archaeologists as the Eastern Woodlands. The emergence of these shatter zones can, in many ways, be considered as archetypal examples of colonial-Indigenous interaction and exploitation during the age of European global expansion (see also White, 1991; Wolf, 1997). According to Ethridge (2006: 208), the impacts of colonial interaction and its associated vectors, including the introduction of global capitalism and Old-World disease, precipitated a dramatic rise in conflict and slaving that shattered the lifeways of Native American groups. The resulting processes of coalescence and ethnogenesis led to the formation of new societies whose identities and practices reflected the changes that had been wrought on the socio-political and cultural landscapes.

Before continuing, it is important to emphasize that the discussion below is intended to highlight how the emergence of a shatter zone manifests at varying temporal and spatial scales in the archaeological record. In examining colonial-Indigenous interaction within this particular space and time, the narrative presented here not only describes but also simplifies a pivotal period in the histories of many Native American groups. The focus of the discussion on destructive processes - albeit presented within a context of long-term transformation-represents a partial and etic viewpoint on foundational developments in the genesis of contemporary nations (see Atalay, 2006: 280-84). 
These events in themselves represent just a short moment in time within the much longer term, lived histories of Indigenous societies, which were not only experienced in different ways by different groups, but which are retained, embodied, and actively expressed in numerous ways today (Silliman, 2005: 59-62, 2009: 116).

When studying the impacts of colonial-Indigenous interaction in the Eastern Woodlands, it is necessary to state from the outset that pre-contact lifeways were not static. In the Mississippian South, competing chiefdoms had co-existed alongside and fought each other for centuries. The emergence of Mississippian culture has been argued by Robin Beck (2016: 458) to 'lie at the intersection of mounds and maize', the former of which began to be constructed at habitation sites as early as c. 5700 cal B.P. The large platform mounds that dominated habitation complexes served various functions, for example, as elite dwelling places and as the sites of temples and mortuary structures, and in this, they represented focal points of interaction and power within regional territories (Cobb, 2003; Sherwood \& Kidder, 2011). During the Late Woodland period, the intensification of maize-based agriculture provided a means by which polities could sustain increasingly large populations, leading to the emergence of societies that are characterized as chiefdoms in around 1000 CE (Cobb, 2003: 63).

The distribution of power within chiefdoms varied regionally; while at least some appear to have been politically centralized and dependent on the maintenance of close ties between groups, others likely comprised networks of more autonomous polities. In a few cases, several polities came together to form so-called 'paramount chiefdoms' that exhibited varying degrees of political integration (see further discussion in Blitz, 2010; Cobb, 2003; Lulewicz \& Coker, 2018). It has been argued that the authority of elites was intimately connected with militarism and success in warfare, as well as ritual practices that cemented their roles as divine or sacral leaders. The redistribution of maize and other local products within elite-controlled networks similarly served as a means by which power was negotiated and reinforced at the intra-polity level (Cobb, 2003: 73; Dye, 2006: 101-2; Miller, 1997: 42-52; Stauffer, 2020). Studies of diet and subsistence have revealed stark differences in the access to resources accorded to higher- and lower-status groups (see, e.g. Ambrose et al., 2003; Thompson et al., 2015), with repeated phases of mound construction noted at some sites further attesting to the reaffirmation of dynastic power over multiple generations (Mehta, 2019). Elites also maintained access to and participated in long distance trading and exchange networks of varying scale. The materials obtained through these, including exotic objects such as engraved shell gorgets and painted ceramics, were funnelled into redistribution networks and used to project an ostentatious material identity as revealed in excavations of burials associated with habitation mounds (Beck, 2016; Lulewicz \& Coker, 2018; Scarry, 1994: 169-70).

The lifecycle of the Mississippian chiefdoms was to a great extent characterized by both internal and external conflict, which served as a catalyst for polity formation, maturation, and fragmentation. Because of this, the geopolitical landscape was constantly evolving. Individual acts of war ranged from small-scale raiding and opportunistic attacks to larger scale assaults on defended settlements, with the rise and fall of individual chiefdoms leading to a 'cycling' of power and influence between polities (Blitz, 2010: 8-9; Ethridge, 2010: 17-18; Jennings, 2009: 273-4). When powerful chiefdoms fell, others rose to fill the vacuum, with the constituent populations of the former relocating in order to join other chiefdoms or re-establish themselves elsewhere. Some settlement complexes 
such as that at Etowah in Georgia were razed and/or abandoned and then later reoccupied several times, while others such as that at Moundville in Alabama experienced only a single period of fluorescence (Dye, 2006: 111-12, 118-19).

When viewed within longer term models of adaptive cycling and disentanglement, the polities of the Mississippian South appear, at a regional level, to have existed within a fragile state of socio-cultural stability (Hally, 2006; Lulewicz, 2019; Lulewicz \& Coker, 2018). While any individual polity was liable to collapse in the face of prolonged stress (resulting from resource scarcity or warfare, for example), the cycling of chiefdoms meant that existing cultural institutions were constantly reinforced by elites looking to establish and consolidate their authority as power ebbed and flowed across regions. If conceptualized within a panarchy framework, we might envisage individual adaptive cycles - each representing a population group - as progressing through their own processes of release and reorganization over generations (compare, for example, with Marcus, 1998, 2008). The systems of internal redistribution and longer distance exchange upon which elites depended, however, would have been inherently vulnerable to fragmentation. As noted by Maureen Meyers (2016: 395), the maintenance of power structures based on the control of prestige-good networks meant that the integrity of both elites and communal structures might have quickly been called into question if the relationships governing interaction between actors suddenly changed. When aligned with Saltini Semerari's (2017) disentanglement model, disruption to networks such as those maintained by the Mississippian chiefdoms would have had the potential to destabilize the very power structures upon which elites depended for survival. The mutual adherence of these polities to a broad, culturally embedded package of structures, practices, and ideological beliefs, furthermore, may have also made these collectively vulnerable to fragmentation if they were successfully challenged (see discussion below), thereby contributing to crises across multiple polities.

In Iroquoia, the political landscape was similarly dynamic and fluid. Between the thirteenth and fifteenth centuries, evidence for increased growth and integration among communities speaks to an intensification of politogenesis. This can be seen archaeologically, for example, in village aggregation, the maintenance of communal ossuaries and sweat lodges, and the emergence and proliferation of pipe smoking as a distinctive cultural tradition that reflects increased alliance-making and diplomacy at a regional level (Birch, 2015: 280-82; Dermarkar, 2019; Hart et al., 2016). It is around this time that coalescent tribal nations comprising large villages or sub-regional settlement clusters emerged. Processes of politogenesis prompted higher levels of social integration; changes in settlement size, structure, and complexity; and the emergence of asymmetrical social structures (Birch, 2012, 2015: 288). Social order was upheld by councils, which existed at numerous levels within the organizational hierarchy and which exercised the power to preside over and settle feuds and disputes through the distribution of wampum (Bradley, 2011: 26-27; Lutz, 1998). The institutionalization of these councils meant that they, and the individuals who presided over them, became indispensable to the daily operation of society. Over time, some nations coalesced further, leading to the formation of the Iroquois (Haudenosaunee) confederacy and, later, the Huron (Wendat) confederacy.

With these changes came increased potential for conflict. As in the Mississippian South, raiding and warfare had probably been taking place for millennia (Richter, 1992; Fox, 2009:63). This activity was usually connected to longstanding inter-group 
feuding, which fulfilled a number of social functions by providing an outlet for communal aggression. Conflict also served as a means of maintaining spiritual balance among communities, and for young men it represented a means of achieving manhood and enhancing one's social status. Cranial remains recovered from middens and storage pits at a number of sites, such as the Adams and California Ranch sites, attest to the importance of trophy taking as a means of attaining prestige (Birch, 2015: 283; Engelbrecht, 2003: 132; Sublett \& Wray, 1970: 22; Wray et al., 1987: 247-48). Another aspect of Indigenous conflict was the so-called 'mourning war'-raids undertaken as an expression of grief intended to avenge those killed in earlier conflicts. An important element of these raids was the securing of captives, who were either killed or adopted by grieving families (Birch, 2010; Ethridge, 2006: 209, Ethridge, 2009a: 29; Starna \& Watkins, 1991: 37-38; Snow, 1994). Collectively, these practices fed into self-perpetuating cycles of warfare that were institutionalized within the culture of Northern Iroquoian communities (Williamson, 2007: 193). Later, they would play a major role in the destabilization of the geopolitical landscape.

When situated against the panarchy framework, the general trend towards politogenesis evident in the archaeological record of the eastern Great Lakes region provides a context for increased social integration, complexity, and volatility. Conflict intensified in line with increasing socio-political complexity during the late-fifteenth and early-sixteenth centuries. This likely reflects increased pressure on hunting grounds as well as the increasing number of warriors who were available to participate in warfare (Birch \& Williamson, 2013; Birch, 2015: 283-84; Birch et al., 2020; Warrick, 2008: 141-42). With the formation of the Haudenosaunee confederation, the conflicts that had previously existed between member nations were directed outwards towards their neighbours (Birch, 2020). Aggregated, fortified settlements situated in defensible locales became more common, with Haudenosaunee attacks on Wendat communities leading to population displacement and the creation of uninhabited buffer zones between polities. These attacks ultimately served as a catalyst for the formation of the Wendat confederacy. While the overall progression of conflict in the region is difficult to determine given evidence for variable and localized trends in village fortification and coalescence (see Birch et al., 2020: 22-23), the emergence of a defensive landscape characterized by the formation of buffer zones, fortified settlements, and military coalitions may nevertheless attest to increasing tension in the centuries preceding European contact (see Birch et al., 2020: 22-24; Fox, 2009: 6465 ). Viewed from a top-down perspective, we might envisage these developments as being representative of the social growth and development that reflect the exploitation and conservation phases of the adaptive cycle.

Further insights into the conditions underpinning the formation of the shatter zone can be gleaned from the internal structures of the Haudenosaunee and Wendat confederacies (for an in-depth discussion, see Birch, 2020). While the Wendat maintained inward-looking networks that were characterized by high levels of connectivity, reciprocity, and mutual trust, those of the Haudenosaunee relied on the reinforcement of relatively loose socio-political connections that reflected their large ancestral territory (Birch \& Hart, 2018; Birch et al., 2020: 427, 435). Stability was maintained through formal diplomatic dialogue that reduced potential for internal conflict, supported by several institutions including the 'Roll Call of the Founders'-fifty chiefly titles that were distributed among its five nations as a means of establishing an overarching 
political structure - as well as the exchange of wampum and communal mourning rites (Birch, 2020: 429-30). When viewed from a perspective of (dis)entanglement, the formalization of trade and exchange as an aspect of Haudenosaunee diplomacy speaks to the cultural importance placed upon access to specific materials as a means of sustaining cohesion and solidarity, thereby leading to increased levels of humanthing and human-human entanglement. The maintenance of relatively loose ties that bound autonomous communities together, however, also permitted contact and exchange with external parties (Birch \& Hart, 2018: 16-17). As we shall see below, these disparate network structures may have had significant implications for future interaction with Europeans from the early-mid seventeenth century onwards.

The formation of shatter zones in the Eastern Woodlands was marked by a period of increased instability and turmoil that began in the decades following contact with Europeans. In the Lower South, early Spanish expeditions such as the 'entrada' led by Hernando de Soto in 1539-1542 appear to have served as a driving force for the destabilization of a number of chiefdoms. Although fine-grained chronologies for this period are lacking, the defeat of Mississippian forces by de Soto's army may have led to a loss of confidence in political elites and undermined the mutually supportive sociopolitical and ideological structures that formed the basis of order within polities (Jennings, 2009: 280; Scarry, 1994: 172-74). The fragmentation of well-established elite institutions and gift-exchange/trade networks would have similarly contributed to the erosion of intra- and inter-group relationships and accelerated the breakdown of connectivity across social strata. Evidence for increased dietary stress among communities, furthermore, may similarly attest to the plundering of local food stores by the Spanish, impacting not only the population's ability to feed itself but also elitecontrolled distribution networks that were supposed to mitigate for periods of hardship (Ethridge, 2010: 60-61; Jenkins, 2009: 234). Collectively, these factors would have led to the disentanglement of the co-dependent relationships that had existed between elites and the wider population (see Hill, 1996; Jenkins, 2009: 234-35; Larsen et al., 2001). The Spanish presence itself also acted as a destabilizing force within diplomatic networks given their capacity to act as an ally, trading partner, or enemy based on their relationship with individual chiefdoms (Worth, 2002). While the potential impacts of Old-World diseases on population levels during this early period in the South are debated, it is possible that pathogenic factors also presented a threat to communities (see, e.g. Larsen et al., 2001; Milner, 1980; Ramenofsky \& Galloway, 1997; Smith, 1994).

It is clear from the outset that the impacts of this interaction were catastrophic for many Indigenous communities. When viewed within the broad remit of the panarchy framework, individual chiefdoms (each represented by their own adaptive cycle) can be envisaged as entering into a phase of release associated with their fragmentation. Indeed, by the time contact was re-established with French and English settlers in the second half of the seventeenth century, several chiefdoms had already disintegrated (Jennings, 2009: 280). It is important to note, however, that the decline of these chiefdoms was not uniform and that the ability of communities to adapt to, resist, or pre-empt change would have varied across and within polities. As noted above, the adaptive cycles of the panarchy often move asynchronously, meaning that communities would have maintained varying levels of resilience - for varying amounts of time - in the face of changing conditions (see Holland-Lulewicz et al., 2020). Some, such as the 
paramount chiefdom of Coosa, appear to have weathered the initial impacts of the entrada only to later suffer the disastrous consequences of commercial slaving and epidemics that swept through the region during the seventeenth century (Ethridge, 2009a: 9).

In one sense, the mechanisms that underpinned this process of fragmentation echoed those which had been occurring for centuries. Evidence for the shrinkage or abandonment of the Little Egypt archaeological site in Georgia, and the contemporaneous growth of others such as the Brown Farm site located around fifteen miles downstream in around the $1540 \mathrm{~s}-1560 \mathrm{~s}$, is similar to the patterns of population displacement or contraction that have been observed when polities decline and later reorganize (Ethridge, 2010: 62-64; Little, 2008; Smith, 2000: 43-44). The key difference in this case, however, was the scale at which these disruptions took place. Longstanding cycles of polity formation and fragmentation were interrupted in many regions. As both the panarchy and disentanglement models show, the emergence of instability within individual polities has the potential to trigger a loss of connectivity that cascades through networks. While a number of chiefdoms such as the Coosa paramount chiefdom, noted above, managed to resist the initial destabilization incurred by Spanish expeditions, a general loss of authority on the part of elites has been argued to be seen in the cessation of mound-building projects and a move towards nucleated settlement structures at many sites. The disappearance of high-status goods from burials also attests to disruption within redistribution and trade networks (Jenkins, 2009: 224; Smith, 2000: 89-90). The opening up of new trading opportunities and the creation of European trading hubs on the Atlantic coast, furthermore, would have allowed a far greater number of people to engage in exchange. This effectively overrode the elitecontrolled production and trade networks of earlier periods, leading to an erosion of power at the polity level (Blanton et al., 2021; Hall Jr., 2009: 33-38; Hally \& Smith, 2011; Meyers, 2016: 397).

As chiefdoms fragmented, their constituent populations moved elsewhere (Blanton et al., 2021; Little, 2008). Evidence for population displacement in central Alabama, for example, is provided by the disappearance of distinctive regional pottery styles and the emergence of new ceramic traditions that placed an emphasis on coalescent identities (Jenkins, 2009: 226). In addition to the cessation of mound-construction projects, evidence for the construction and use of council houses further suggests a realignment of socio-political networks towards more communally oriented hierarchies and structures. In time, these council houses would become foci of communal identity within historic towns, with the dispersal of power and influence across social strata preventing prospective elites from re-establishing the kinship-driven networks that had underpinned social and political structures during earlier periods (Marcoux, 2010: 137; Saunders, 2017: 55; Scarry, 1996; Rodning, 2002, 2009).

While the impacts of early Spanish incursions played a major role in destabilizing the southern chiefdoms during the sixteenth century, the effects of colonial disruption in Iroquoia were not felt until almost a century later, when the French and the Dutch began to establish colonies in what is now Quebec and New York state. These developments coincided with and precipitated an intensification of pre-existing rivalries between groups who sought to monopolize the European trade. Archaeological evidence suggests that European goods - mostly comprising pieces of copper, iron, and brass in modified form - had begun to enter into Indigenous networks through trade 
during the sixteenth century. While recent work by the Dating Iroquoia project has indicated that access to these goods may have been restricted by certain groups at an early stage (see Birch et al., 2020: 23-24), the flow of trade goods into Native communities increased rapidly in later periods. As in the South, the cultural importance that was quickly ascribed to European goods created new 'chains of consumption', which drew Indigenous communities into a series of new and deeply entangled relationships that revolved around the procurement of commodities (Carter, 2008; see also White, 1991: 99-100). European traders-and in particular the Dutch-also inserted themselves into wampum production and distribution systems, thereby establishing themselves as key economic agents within Indigenous exchange networks (Bradley, 2011: 31-36; Peña, 2001).

In return for guns, wampum, and other trade goods such as cloth, copper and brass kettles, and beads, European traders demanded furs and captives. This inflamed longstanding rivalries between the Haudenosaunee and the Wendat, providing the context for an intensification of conflict as raiding parties sought to clear the landscape with a view to monopolizing access to hunting grounds. The Haudenosaunee practice of engaging in exchange as part of diplomatic contact (see discussion above) may have afforded the confederation an additional measure of flexibility in establishing relationships with the newcomers, providing them with a competitive edge over their neighbours who maintained more inward-looking networks (Birch \& Hart, 2018: 16). The Dutch and later British provision of the Haudenosaunee with guns also gave them a distinct edge over the Wendat, who did not have the same ability to obtain these materials from their French allies, as well as neighbouring nations such as the Wenros and Eries (Birch, 2015: 299-300). In a situation similar to that in the Mississippian South, Europeans came to represent a destabilising force within Indigenous networks, which could be harnessed by Native groups even as the former attempted to exert their own influence over individual nations through trade and diplomacy.

While cultural behaviours governing the conduct of warfare might have normally served to limit the disruption caused by the reorientation of trading networks, there was no defence against the devastating effects of Old-World diseases, which are first recorded as sweeping across the region from the 1630s (Fox, 2009: 64; Labelle, 2009; Snow, 1994: 111; Warrick, 2008). Raiding intensified further, leading to a fragmentation of lifeways that finds accord with the process of release within the panarchy framework. It has been suggested that a disproportionate number of deaths among community elders, which would have included council members and lawmakers, may have precipitated a loss of structure, regulation, and social cohesion within networks, leading to the destabilization of social hierarchies and a shift in control to younger warriors who were eager to participate in successful raiding ventures (see Birch, 2015: 299; Fox, 2009: 64-65; Mesquida \& Wiener, 1996, 1999). The loss of experience and knowledge from the death of elders and those who traditionally led hunting expeditions may have also impacted communities' subsistence capabilities, as seen, for example, at the Wendat site of Ellery in Ontario, where communities appear to have become increasingly reliant on more locally sourced animals obtained through passive means of hunting (see Hawkins et al., 2018). The cycle of mourning wars, which had traditionally provided communities with an outlet for their grief, went into overdrive as increasing numbers of captives were sought to replenish decimated populations (Richter, 1983: 540). Evidence for this can be seen, for example, in the 
recorded capture and assimilation of several hundred Algonquian-speaking prisoners by the Neutrals in 1643 (Trigger, 1987: 624-25).

As levels of violence increased, it was the Haudenosaunee who would emerge as the dominant martial power in the region. Increasingly frequent and destructive Haudenosaunee raids resulted in the displacement of the Wendat, the Neutrals, and the Petun in 1649, 1650, and 1651, respectively. The Eries were similarly defeated at some time between 1654 and 1657 (Ethridge, 2009a: 30; Fox, 2009: 65; Jennings, 2009: 281). The hardships endured by those who survived these attacks may be evidenced at a Neutral cemetery excavated in Grimsby, Ontario, where the last phases of use at the site are characterized by multiple burials of people who appear to have died within a short time span, perhaps of famine or disease (Jackes, 2008; see also Trigger, 1987: 770-87). Other groups coalesced with neighbouring communities or were incorporated into the societies of their captors (Ethridge, 2009a: 29; Fox, 2009: 70; Meyers, 2009: 85). It has been suggested that the establishment of satellite communities situated on the peripheries of core Haudenosaunee territories reflects the integration of displaced peoples into multi-cultural settlements (see Jordan, 2013; also Feathers, 2006; Michelaki, 2007).

In many cases, this process of assimilation would have served to erase the cultural identity of defeated nations from the landscape (Ethridge, 2009a: 29; Fox, 2009: 70; Lynch, 1985; Meyers, 2009: 85; see also James, 2018 for a comparative perspective). The identification of atypical burial practices at some Haudenosaunee satellite settlements and later principal towns, however, may indicate that the populations inhabiting these sites were developing new, politically charged customs that found their expression in funerary rites. This suggests that communities were engaging in complex processes of cultural dialogue, negotiation, and re-entanglement even as the shatter zone was unfolding in the landscape around them (Jordan, 2018).

When taken together, the available evidence indicates that, by the middle of the seventeenth century, at least two regional shatter zones had emerged in the Eastern Woodlands - one amongst the chiefdoms of the Mississippian South and another in Iroquoia. As crises intensified, 'shock waves' in the form of population movements and slave raids began to resonate out across the wider landscape. Disruption to agricultural practices and trade networks, the breakdown of elite power structures, captive-taking and slaving, epidemics, and famine all became major threats or realities (Ethridge, 2006: 208; Kelton, 2009: 321; Shuck-Hall, 2009; Worth, 2009: 296). In the north, many groups looking to escape Iroquois raids fled west - into the region of the Western Great Lakes, which would become the setting of Richard White's 'middle ground' (see White, 1991: 12-13). Others moved south, into what is now Virginia, the Carolinas, and the Lower South (Ethridge, 2010: 116-48; Jeter, 2002: 185, 213-4, Jeter, 2009: 373).

The effects of population movements and their potential role as a destabilizing force have long been a topic of discussion among historians and archaeologists (for recent discussions, see Cline, 2014; Driessen, 2018; Heather, 2010). In the present case, these movements can be seen as acting as a bridging mechanism that, when combined with British and French settlements on the southeastern seaboard and the lower Mississippi River valley from the late seventeenth century, led to the fusion of two shatter zones into a single entity. Some groups such as the Richahecrians-Westos, who are thought to have migrated from the southern shores of Lake Erie to the area of present-day Virginia and South Carolina during the 1660 s, turned to captive-taking as a means of surviving 
predation by other tribes (see Fox, 2009: 71-2; Meyers, 2009: 83-86). The combined impacts of raiding by the Westos and other predatory groups led to widespread depopulation in areas of the southeast and Lower South (Ethridge, 2006: 210, Ethridge, 2010: 98-107; Beck, 2009: 134-5, Beck, 2013: 152-53 Bowne, 2009: 111; Fox, 2009: 71, 75; Jennings, 2009: 282-3).

These movements served as a further disruptive influence in regions that were already under considerable strain. The northern and southern Eastern Woodlands were linked by a complex and ancient network of communication and trade routes that now facilitated inter-regional raiding and the transmission of disease. Thus, as seen in the interconnected framework of the panarchy, there was clearly potential for developments taking place within one region (or adaptive cycle) to influence others. In the south, those chiefdoms that had endured the impacts of the initial European incursions began to fall prey to raiding, slave-taking, and later disease. The consolidation and expansion of European influence also served as a point of increased tension, as colonists and Native groups attempted to manipulate one another as a means of furthering their own interests (Beck, 2009: 134; Snyder, 2010: 116; Shefveland, 2016: 44-60).

Insofar as raiding had the potential to further destabilize and drive the fragmentation of polities and networks, however, so too did this provide an additional impetus to ongoing processes of coalescence. These developments can be perceived as marking a formative point in the adaptive cycles of the panarchy, when the restructuring and reorganization of lifeways begins gain traction within a broader context of release. Those regions that managed to avoid the predations of slavers became foci of integration, leading to the rise of multi-lingual, coalescent nations such as the Creeks, Chickasaw, Catawba, and Yamasee (Beck, 2009: 137; Bowne, 2009: 107; Jenkins, 2009: 236; Snyder, 2010: 115-16). Potential archaeological evidence for coalescence can be seen at the Townsend site, an 'improvised' late seventeenth- or early eighteenth-century Cherokee settlement in eastern Tennessee, where excavations have documented several distinct potting traditions in the ceramic assemblages from the site (see Marcoux, 2010: 105, 143). The clear association of these traditions with individual households has led Jon Marcoux $(2010: 107,140)$ to argue that the site was occupied by recent immigrants from several Cherokee territories who possessed knowledge of regional potting traditions. Evidence for a previously undocumented pottery tradition may also attest to the creation of new material identities that emphasized communal solidarity during a time of instability and hardship (Marcoux, 2010: 141). The short life of the houses at the Townsend site also implies a break from past traditions. In contrast to earlier Mississippian communities, which occupied and rebuilt their houses over generations, those analysed by Marcoux were more ephemeral and occupied at the most for perhaps a decade. Marcoux (2010: 137) interprets this as indicating that houses no longer functioned as an 'anchor' for community identities; rather, as noted above, communal buildings such as townhouses were beginning to fill this role (Rodning, 2009).

Further evidence for fundamental changes in lifeways can be charted in the active efforts of some communities to adapt to a lifestyle framed by uncertainty. These strategies, which align with those predicted by behavioural ecology models for communities suffering from food stress, can be seen in the modification of subsistence practices within individual settlements (Marston, 2011). In a study of botanical 
remains from the Jenrette site in North Carolina, for example, Mallory Melton (2018: 215) found that subsistence practices in the Eno river valley during the late seventeenth century shifted towards an increased reliance on foraged foods and that communities also introduced field scattering as a means of mitigating potential damage to or loss of maize crops. The Jenrette site was occupied for only a short period of time-perhaps only 20 years - implying that the community was also aware of their tenuous position. This led them to prioritize short-term strategies over those that would have ensured longer term security and continuity (Melton, 2018: 2167-17). Wider studies of Cherokee and Catawba communities have similarly yielded evidence for intensified foraging and increased consumption of seasonal, fleshy fruits, which not only grew on the boundaries of agricultural areas close to settlements but also required less processing (Fitts, 2015: 312-15; VanDerwarker et al., 2013).

While some groups adapted their subsistence practices in order to mitigate the potential impacts of instability, others harnessed mobility as a means of avoiding the predations of slavers. The Shawnee, for example, adopted a transient lifestyle after being forced out of their homeland in the Ohio Valley at some point in the 1660s or early 1670 s. While on one hand this would have precipitated a jarring disentanglement of human-place relationships among Shawnee groups, this strategy nevertheless allowed them to maintain cultural resilience in a time when many others were forced to abandon or renegotiate their identities as a means of integration into coalescent societies (Warren \& Noe, 2009: 167-69). The ability of the Shawnee to move between regions and various Native societies allowed them to develop a reputation as cultural intermediaries and messengers, a status which also lent them a degree of both political and spiritual influence when settling in new territories (Snyder, 2010: 115).

With the shattering of pre-colonial lifeways, Indigenous communities began to adapt to a new life in an unstable world. By the eighteenth century, disease and warfare had taken a huge toll on the population of the Eastern Woodlands, decimating once populous and thriving regions. Coupled with famine and later European colonial expansion, these factors contributed to the mass displacement of populations and their coalescence in regions of refuge. Subsequent processes of 'tribalization' and ethnogenesis (Ferguson \& Whitehead, 1992: 3), however, would have led to a re-entanglement of relationships between communities, objects, and places. This reconstitution of lifeways can be taken as a move towards a new stage of socio-political development that roughly corresponds with the reorganization and subsequent exploitation phases in the adaptive cycles of the panarchy (Holling, 2001: 394; see also Ethridge, 2006: 210; Fitts, 2015; Jenkins, 2009: 234-6).

The re-entanglement of native communities and networks in the South was marked by the re-emergence of political and social structures, agricultural practices, and traditions that both echoed and differed from those of the pre-contact period. In some cases, this necessitated a wholesale 'rewiring' of social relationships that reflected the new identities and needs of population groups. Cultural memories of the violence that gave rise to the emergence of coalescent nations such as the Creek, for example, were preserved in origin stories that represented a fundamental element of new collective identities that bound disparate groups together (Hall Jr., 2009; Jennings, 2009:288). Archaeological material from a number of sites similarly provides evidence for complex processes of ethnogenesis and cultural negotiation, with evolving pottery traditions - as noted above at the Townsend site - attesting in some cases to a fusion 
of working techniques and cultural identities (Ethridge, 2009a: 40, Ethridge, 2010: 66, 68; Jenkins, 2009: 224; Marcoux, 2010: 141; Nelson, 2020). Evidence for disparate trends in body ornamentation among Catawba communities during the eighteenth century, as well as the production and use of pottery types that echoed earlier seventeenth century and prehistoric wares, however, also indicates that new practices were balanced with and adopted alongside older traditions (Jenkins, 2009: 226). This latter suggestion finds further support in studies of foodways, which have indicated that different communities within coalescent societies retained aspects of their previous culinary practices even during times of instability and food stress (Fitts, 2015: 315-19; Cranford, 2018). These variable cultural practices, which can be identified only at local levels, speak to the many selective acts of negotiation that framed ongoing processes of re-entanglement or reorganization.

In relation to this, we should not presume that the process of coalescence did not involve coercion or subjugation. As Christine Snyder (2010: 116-18) has noted, refugee groups that sought shelter among nations such as the Creek were liable to be incorporated into existing social structures as subordinate members of the community. The Creeks' reputation as powerful and successful warriors meant that the nation was wellplaced to absorb the remnants of previously scattered polities. Bioarchaeological studies of a seventeenth-century Spanish mission community at Santa Catalina de Guale, Florida, have similarly indicated that Guale communities retained the hierarchical structures of pre-contact Mississippian society despite incorporation into the Spanish mission and heavy depopulation as a result of disease, food stress, and exploitation (Larsen et al., 2001; Winkler et al., 2017). In this case, the maintenance of pre-contact hierarchies would have allowed elites to maintain preferential access to resources during a time in which population groups were vulnerable to unstable conditions. The enforcement of social stratification among the Guale therefore reflects a very particular form of the re-entanglement process highlighted by Saltini Semerari (2017: 548), who notes that the primary actors in networks may draw on past traditions as a means of re-establishing stability and connectivity in the wake of disruption.

While some communities managed to preserve vestiges of their pre-contact social structures and traditions, other aspects of Indigenous lifeways were incompatible with the changes that had been wrought on the landscape (Ethridge \& Hudson, 1998: 38; Ethridge, 2009a: 36-42). A major point of departure from the pre-contact period can be seen at both local and regional scales in the reorientation of trade networks and political economies (Beck, 2009: 138). Interaction with Europeans brought with it a flow of new materials and technologies into the North American interior. Efforts to obtain these materials led coalescent groups to take advantage of new economic opportunities. While the true extent of the Indigenous slave trade will likely never be accurately quantified, the explosion of the accompanying fur trade is reflected, for example, in faunal assemblages from numerous Chickasaw sites in the vicinity of Tupelo, Mississippi, which indicate a major shift in hunting practices towards the exploitation of beaver, fox, raccoon, mink, bobcat, cougar, and wolf populations (Johnson et al., 2008). Items initially traded between Native communities and colonists, furthermore, quickly found their way into Indigenous trade networks, and European trade goods and weapons that had originally been held and circulated within elite-based gift-exchange networks became indispensable for daily life, leading to the formation of new entangled relationships between people and materials (see, e.g. Legg et al., 2019). Excavations of 
an Occaneechi settlement at Fredrick's Site in North Carolina have yielded a range of European materials ranging from guns and gun parts, to lead shot and gunflints, to everyday tools such as knives, hoes, bottles, and spoons and over ten thousand glass beads - a ubiquitous and inexpensive commodity that was sought by Native communities (Ward \& Davis Jr., 1993; 429: Beck, 2013: 173-74). The importance placed on access to and control of the European trade is further attested by the strategic positioning of Indigenous settlements on major trade routes between the coast and the interior, as well as later efforts of communities to strengthen diplomatic and economic ties with colonists in order to prevent interference from their neighbours (see, e.g. Beck, 2013: 122, 174; Hally \& Smith, 2011; Piker, 2004: 39-30).

Evidence for these complex, entangled networks of communication and exchange can be seen in the so-called Catawba Deerskin Map, an Indigenous map produced for the colonial governor of South Carolina in around 1721. The map, which provides a heavily stylized overview of the distribution of Native American tribal groups - most prominently the Catawba, Chickasaw, and Cherokee - located between English-held Charleston, Virginia, and the Mississippi River (see Fig. 2), reflects not the geopolitical reality of the shatter zone so much as a cognitive representation of inter-group relationships within this continuously evolving sphere of interaction. The map highlights not only the inter-connectedness of the groups inhabiting the region but also their efforts to maintain individual trading and communication links with the English colonies. It is, in effect, a rather remarkable and perhaps uniquely tangible expression of the (dis)entanglement concept overlain on the earlyeighteenth-century landscape. These relationships had to be carefully managed, and it is not difficult to imagine how tensions and competition might have arisen as groups jockeyed to maintain, control, or monopolize access to trade (Chambers, 2013: 214; Galloway, 2009).

As the eighteenth century wore on, the settled landscape would continue to be moulded and shaped by colonial expansion and domination. For some groups, survival necessitated cultivating closer relationships with the colonies that bound Indigenous peoples and Europeans into complex relationships of mutual dependence (Fitts, 2015: 311). At the local level, efforts to plug into and benefit from access to trade networks led individuals to mobilize their specialist skills in new occupations such as commercial hunting, trapping, and guiding (Ethridge \& Hudson, 1998: 41-45; Ethridge, 2009a: 402). In time, the efforts of various Native groups to establish a monopoly over trading networks would precipitate the rise of a second generation of militarized slaving societies whose own internal structures were riven by factional disputes (Ethridge, 2010; Fitts, 2006). There is evidence, for example, to suggest that intensive slave raiding played an influential role in reshaping leadership patterns among the Chickasaws, with the desire to hold influence in matters relating to trade leading to a breakdown or disentanglement of social relationships and hierarchies between unilineal kinship groups or moieties. This resulted in increased factionalism and competition that drove moieties to align variously with the British or French as a means of garnering support for their cause, thereby cementing the status of Europeans as vital agents within re-entangled networks (Ethridge, 2009b: 263-7). Just as Native communities sought to harness the influence of the European colonists, however, so too would the latter seek to exploit their position by enlisting the help of various nations to break the stranglehold of others on the Indigenous slave trade. This ensured the perpetuation of cycles of violence that would continue to erupt moving into the latter part of the century (Beck, 2009: 138; Ethridge, 2010: 155; Fitts \& Heath, 2009: 149). 


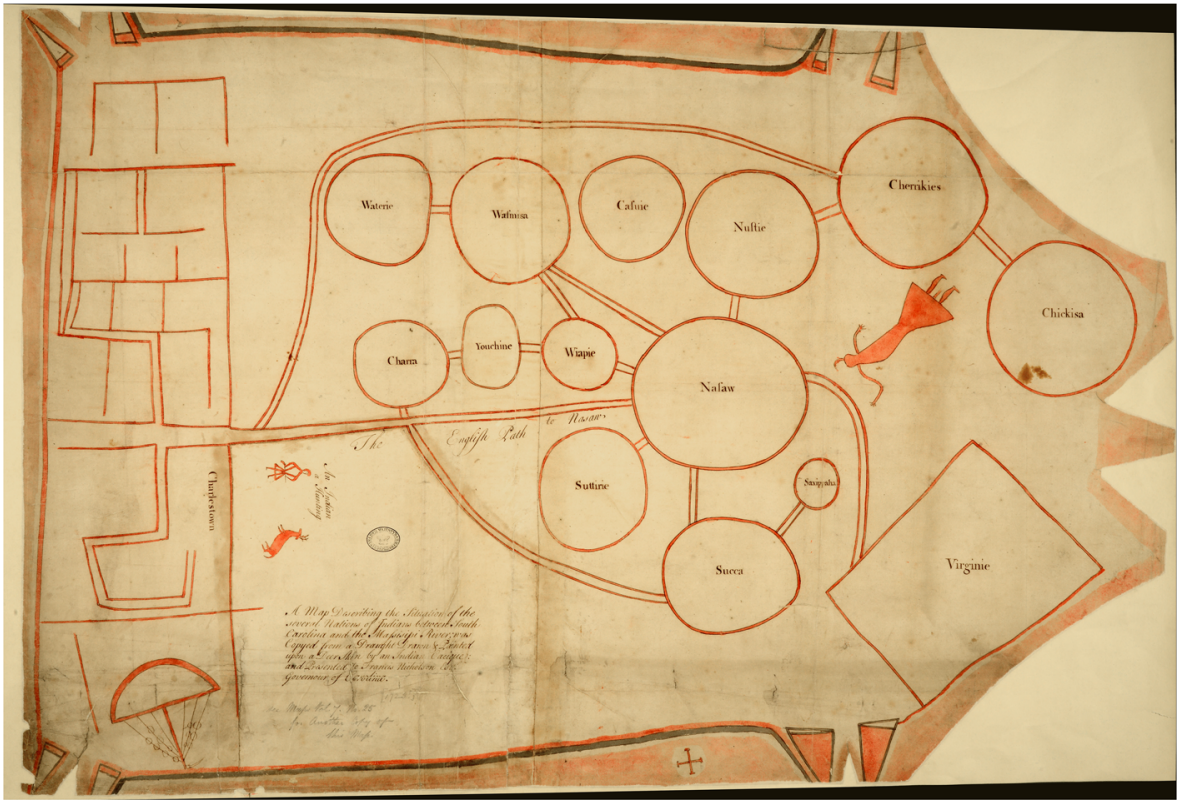

Fig. 2 The so-called Catawba deerskin map, produced in around 1721, which highlights the interconnected nature of the groups inhabiting the region between Charleston and Virginia, in what is now South- and North Carolina. The double-lined routes indicate lines of communication and trade between European and Native communities. Note that the map is oriented with west at the top of the image. Image reproduced with the permission of The National Archives, London; Colonial Office Library 700, North American Colonies 6(1)

\section{Towards an Archaeology of the Shatter Zone}

Although it is impossible to provide more than a superficial summary of the events taking place across the Eastern Woodlands during the sixteenth to eighteenth centuries, it is clear that the emergence of a shatter zone is underpinned by a number of both long- and short-term developments that, in this case, proved formative in the realignment of Indigenous lifeways. The purpose of the discussion above was to align these processes with the conceptual frameworks offered by the panarchy and disentanglement models while also exploring the range of evidence that might be mobilized to study shatter zones from an archaeological perspective. In this section of the text, I will draw attention to a range of 'proxies' that can be used to identify and explore shatter zones in the material record. The discussion here is not intended to be exhaustive but rather to highlight just some of the many forms of data that have the potential to shed light on the ways in which populations experience and adapt during periods of profound social transformation.

The emergence of a shatter zone is a complex development, reflecting the cumulative impacts of myriad forces that combine in order to initiate disruption across every level of society. This leads not only to destruction but also innovation in the ways in which communities both strive to resist and adapt to change, even if these strategies are in themselves highly parochial. These 
decisions in turn set the stage for new phases of social and political development and the reforging of lifeways over the course of multiple generations. Archaeologists are uniquely well-positioned to study the vast quantities of 'small' data that speak to these changes, and which collectively provide the basis for a bottom-up approach to the study of shatter zones that can be mobilized as a means of augmenting and nuancing broader narratives of historic transformation (see Kowalewski, 2006: 117-18; González-Ruibal, 2014: 48).

As noted in previous studies, the study of settlement structure and the built environment offers numerous opportunities to trace the ways in which episodes of transformative change can be compared both diachronically and cross-culturally (see, e.g. Beck et al., 2007). Variation in political consolidation and decentralization at a regional level, for example, can be inferred from changes in settlement structures, fortification construction, and targeted studies of high-status or monumental architecture (see, e.g. Marcus \& Flannery, 2003: 217). It has also been argued that the study of settlement architecture may offer insights into processes of migration and coalescence at both local and regional levels (see, e.g. Struever, 1964; Clark, 2001; Jeter, 2002, 2009; Meyers, 2009: 87). In the Eastern Woodlands, changes in settlement size, morphology, and location provide a context for the discussion of politogenesis and the militarization of the landscape in the Great Lakes region in the centuries preceding contact with Europeans. These also reflect the formation of the confederations that would later represent the primary protagonists in the conflicts that drove the formation of the shatter zone in Iroquoia (see, e.g. Birch, 2010, 2016; Birch et al., 2020). In the Mississippian South, the study of settlement emergence, growth, reduction, and abandonment similarly allows scholars to better undestand not only the lifecycle of chiefdoms, but also the conditions that would later underpin the destabilization of polities in the postcontact period. The formation of the Mississippian shatter zone itself comprised a largescale rupturing of the built environment, represented for example in changes to settlement layout, the cessation of monumental construction projects, and the growing importance ascribed to council houses. Collectively, these changes attest to a disentanglement of the elite networks and power structures that had previously upheld sociopolitical continuity among Mississippian societies and with this the establishment of a new baseline for the restructuring of social hierarchies (see, e.g. Rodning, 2009; Saunders, 2017).

Given the widespread instability that is inherent to the formation of a shatter zone, this process is also characterized more generally by disruption to the rhythms of daily life that manifest both regionally and locally. The study of variation in subsistence practices, foodways, production, trade, and occupational activity has the potential to speak to the nature of this disruption, as well as the implications of this for both individual communities and regional populations. In connection with the changes in settlement morphology discussed above, for example, the reduced lifespan of houses at the Townsend site noted by Marcoux (2010) reflects a tacit recognition of the uncertainty that permeated the lives of the nascent community residing there. Evidence for changing subsistence practices and foodways at the Jenrette and Ellery sites similarly reflects efforts of communities to mitigate for the impacts of resource scarcity, conflict, disease, and displacement by prioritizing short-term needs over longer term strategies (Hawkins et al., 2018; Melton, 2018). Disruption to trading networks may also be evidenced through the introduction of new cultural materials within burials and 
settlements, as well as a decrease in the visibility of materials that had previously been widely available (see, e.g. Smith, 2000: 89-90; Johnson et al., 2008; Smith, 2000: 8990; Meyers, 2016: 397).

Studies of the burial record can yield data on the ways in which the health and lifeways of communities are impacted during periods of social instability and upheaval. Analyses of osteological material, for example, have the potential to provide information on population health, changes in subsistence patterns and occupational activities, and conflict (see, e.g. Jackes, 2008). ADNA and isotopic analyses can similarly offer insights into population displacement and migration while also providing evidence for processes of coalescence within communities. When combined with osteological studies, this data could also offer a means of identifying subaltern or enslaved populations (for comparative examples, see, e.g. Martin et al., 2010; Martin, 2016; Redfern, 2020). Studies of burial customs and assemblages provide an additional context for discussions of social stratification and the ways in which social structures and elitecontrolled networks shifted over time (see Smith, 2000: 105-11; Ethridge, 2009a: 40, Ethridge, 2010: 66, 68; Winkler et al., 2017).

Conflict, taking place at both local and regional levels, represents another proxy for the emergence of a shatter zone. While conflict should not necessarily be considered a ubiquitous feature of life within a shatter zone, the fragmentation of social and political structures, combined with wider disruption resulting from population displacement, resource scarcity, loss of connectivity in networks, and other destabilising factors all represent potential catalysts for violence. As conflicts escalate, they can contribute to the fragmentation of regional power and social structures and the dissolution of territorial and political boundaries, which itself serves to drive further episodes of violence as the impacts of these developments resonate out into surrounding areas.

At a regional level, evidence for conflict might take the form of increased levels of militarization within the landscape, as seen in morphological changes to settlements, the establishment of fortifications to monitor and control movement, settlement abandonment, and the formation of buffer zones between polities. Evidence for these processes taking place in Iroquoia, as noted above, can be taken as reflecting increasing tensions between the Haudenosaunee and Wendat confederations in the centuries preceding contact with Europeans (Birch et al., 2020). At a localized scale, evidence for conflict includes the violent destruction or abandonment of settlement and occupation sites, the hoarding of valuable materials, and burials bearing evidence of trauma (see, e.g. Anderson \& Cook, 2017). Bioarchaeological studies of burials and mass graves also offer opportunities not only to shed light on methods of waging war but also population health and nutrition as a means of establishing a wider context for violence. Demographic studies can also allow for the tentative identification of captivetaking and slavery (for comparative examples, see Zimmerman, 1997; Teschler-Nicola, 2012; Meyer et al., 2015; Meyer et al., 2018; James, 2018).

As we have seen above, life within a shatter zone is characterized, at a fundamental level, by transformative cultural change. In the case of the Mississippian shatter zone, this is expressed most clearly in the formation of coalescent societies and the increasing entanglement of Indigenous and European lifeways from the seventeenth century onwards. Processes of forced and voluntary migration and coalescence led to the emergence of novel and innovative cultural materials that reflected the diverse and fluid identities of 
population groups working to adapt to life in a changing world (see, e.g. Burmeister, 2000: 542; Jenkins, 2009: 234; Marcoux, 2010: 136-8; Beck, 2013: 230-44; Blewitt, 2016; Sabo III et al., 2020: 31-34). Expressions of identity are embodied, for example, in materials including ceramics, jewellery, and body ornamentation, in technology and production methods, foodways, and ideological beliefs (Scott, 2009: 211; Waselkov \& Dumas, 2009; Marcoux, 2010: 141; Ethridge, 2010: 83-4; Fitts, 2015: 315-19). As at the Townsend site, analyses of decorative motifs and production techniques embodied in pottery assemblages attest to the emergence of coalescent communities and their efforts to establish a collective identity within contexts of instability and disruption (see Marcoux, 2010). The study of burial customs, as seen for example in the case of those used within Haudenosaunee satellite settlements in the eastern Great Lakes region, can also provide invaluable insights not only into the ways in which communities chose to formulate and express new sociopolitical and cultural identities, but also the specific contexts within which these became salient (see Jordan, 2018).

In relation to the above points, there is a need to establish more secure chronologies and contexts for the discussion of archaeological materials. As demonstrated by the Dating Iroquoia project (see Birch et al., 2020), the dating of sites through the study of material proxies alone can introduce a significant temporal bias into the study of key transformative processes. In this case, the establishment of absolute radiocarbon dates for numerous sites has allowed scholars to develop a high-resolution perspective on politogenesis taking place in the Great Lakes region in the centuries before European contact. In addition, it is important to account for potential climatic and environmental factors that might provide a context for regional instability and change. While environmental narratives have yet to be built into discussions of the Mississippian shatter zone (though for discussions of pre-contact chiefdoms, see, e.g. Anderson, 1994; Blitz \& Lorenz, 2006; Cable, 2020), researchers should where possible mobilize available data including that obtained from macro-botanical studies, ice core and tree-ring analyses, and tephra analyses, among others. Although the potential disruptive impacts of climatic instability and their capacity to induce change among human societies have been intensely debated by archaeologists, there is now a growing recognition that these do have the potential to generate high-stress and unstable conditions (see, e.g. Butzer \& Endfield, 2012: 3268; Drake, 2012; Turner \& Sabloff, 2012; Diaz \& Trouet, 2014; Price \& Gräslund, 2015; Bradtmöller et al., 2017; Arponen et al., 2019). It has recently been suggested, furthermore, that extended periods of favourable climatic conditions can, when viewed from a long-term perspective, provide a context for social upheaval by supporting accelerated processes of social development and population growth that become unsustainable when the climate begins to stabilize (see, e.g. Weiberg \& Finné, 2018). These arguments emphasize the need to examine the emergence of a shatter zone as a cumulative product of interlinked environmental and anthropogenic factors, all of which have the potential to amplify human responses to changing conditions.

Finally, where possible, it is essential that archaeologists engage with written and oral histories, literary sources, and other documentary evidence at their disposal. While the discussion above has focused mostly on broad narratives of cultural change taking place at the inter-regional level, there is significant potential to mobilize various forms of historical documentation (which in a Colonial North American setting includes first-hand accounts 
offered by European explorers, missionaries, and traders) as a means of critically evaluating these. Given the inevitably biased and incomplete perspective offered by the former in this particular case, however, the information contained within can and should be augmented where possible through the consultation of Indigenous histories. As noted briefly above, for example, origin stories have the potential not only to provide remarkable insights into the conditions that gave rise to the emergence of coalescent nations within the context of European colonization, but also the ways in which these histories have provided an anchor for the identities of Indigenous communities since then. Acknowledging the full spectrum of emic perspectives on the emergence of a shatter zone will inevitably yield a more nuanced and inclusive understanding of conditions within these regions, which in turn provides a more secure context for the study of material evidence.

Moving forward, it is apparent that the study of shatter zones has the potential to offer valuable insights into the ways in which populations experience and respond to instability and upheaval. Based on the study of the Mississippian shatter zone, above, it is possible to identify some issues and potential avenues of research that deserve further consideration.

First, there is clearly a need to apply the theoretical frameworks outlined here to other case studies in order to consider the wider applicability of the shatter zone concept within archaeological research. To date, discussions of shatter zones have mainly focused on the impacts of early modern colonial-Indigenous interaction. The Mississippian shatter zone, as Ethridge (2010: 4-5) notes, formed when 'two asymmetrical worlds' collided, and in this, it likely represents just one of many shatter zones that emerged globally in regions subject to European colonial and commercial expansion during the sixteenth to nineteenth centuries (for West Africa, for example, see, e.g. Wolf, 1997; Baum, 1999; Kroot et al., 2019; Diakho \& Gokee, 2020). While many other potential case studies (such as a more-detailed consideration of an 'Iroquoian shatter zone') present themselves, there is also significant potential to develop a comparative, global approach to the study of shatter zones that focuses more broadly on the ways in which human societies experience and respond to widespread socio-political disruption, instability, and cultural transformation. Moving away from the early modern period, potential case studies include that of the so-called 'Late Bronze Age collapse' of the twelfth century BCE, when the societies of the Eastern Mediterranean and Anatolia experienced a disruptive and possibly violent period of socio-political transformation that resulted in widespread cultural change across the region. The shatter zone concept could also be applied to the study of the Roman world during Late Antiquity, when the lives of populations across Europe were dramatically reshaped by the fragmentation of the Western Roman Empire and large-scale migrations of Germanic, Hunnic, and Slavic tribes. A third potential example comprises the broad cultural sphere of the so-called 'Viking diaspora', an area comprising large tracts of northern and western Europe, the Baltic, and central and eastern Europe, which were subjected to intensive raiding and colonization by Scandinavian groups during the eighth to eleventh centuries CE.

In adopting a comparative perspective on shatter zones, archaeological research can shed new light on the 'packages' of conditions that have the potential to prime for both the destabilization and reconfiguration of societies at varying levels of temporal and spatial resolution. As noted previously, the formation of a shatter zone represents the culmination of numerous long- and short-term developments - asynchronous changes 
taking place across different levels of society that intersect at a particular time in order to activate widespread change. Identifying and exploring the ways in which instability manifests in the archaeological record will allow researchers to piece together a material 'footprint' for the emergence of shatter zones, which can then be mobilized as a means of qualitatively documenting the ways in which large-scale transformations impact societies cross-culturally.

The spatial and chronological definition of a shatter zone, furthermore, requires clarification. While shatter zones might be viewed on one hand as sprawling, nebulous regions of socio-political and cultural instability, the arguments presented above indicate that large geographical areas such as the Eastern Woodlands or the Mississippian South might often comprise a number of regional, nested shatter zones - in this case including areas such as the Carolina Piedmont, which collectively make up a greater whole (see Ethridge, 2020). Adopting a finer-grained approach to the study of shatter zones, which integrates regional and intra-regional studies into wider narratives of socio-cultural transformation, would likely yield interesting insights into local responses to instability and change (see individual case studies in Ethridge \& Shuck-Hall, 2009). In relation to this, and as again noted above, it is necessary to moreclosely identify the points in time at which the salient processes of transformation take place, and in doing so to untangle the roles of different factors such as conflict, migration, or resource scarcity as driving or deriving from these changes. This is especially important in contexts where archaeologists cannot rely on detailed narratives provided by historical documents.

Building on this point, scholars should seek to better understand the variant ways in which instability and upheaval have the potential to impact different communities and groups across social strata. In some cases, the emergence of a shatter zone might primarily represent a crisis for either elites or lower-status groups, while in others this process may have the potential to destabilize the lives of entire polities. While recent scholarly work within resilience studies has often focused on human adaptation and innovation in the face of instability (see, e.g. Erickson, 1999; McAnany \& Yoffee, 2010: 10-11; Weiberg \& Finné, 2013: 117; Peterson \& Broad, 2016: 76), this should be balanced with a more critical discussion of vulnerability, parochialism, and an acceptance that periods of change are often highly destructive (Holling, 2001: 395; Schoon et al., 2011; Nelson et al., 2015). Although it is true that some groups might develop innovative adaptive strategies that allow them to withstand and mitigate for change, in at least some cases this ability will come at the expense of others who would remain fully exposed to the 'creative destruction' of the shatter zone (Holling, 2001: 396; Sheets, 2012: 55-56). In the shattered world of the Eastern Woodlands, the life of many communities was governed by cycles of instability and trauma that in some cases lasted for generations. The strategies devised by groups to mitigate for changing conditions were heavily parochial and, in some cases, involved high levels of violence (see, e.g. Beck, 2009; Jennings, 2009).

In relation to this, there is a need to more-closely study the strategies utilized by populations as they seek to reconstruct their lives in the wake of the shatter zone. What cultural factors, for example, facilitate processes of coalescence and politogenesis following a period of instability? What might influence communities to draw on or co-opt elements of previous institutions and cultural traditions, or to experiment with new forms of social organization and interaction? By what means do coalescent 
societies negotiate and carve out new relationships, social structures, networks, and hierarchies and how do changing cultural traditions reflect their newly re-entangled relationships with objects and places? The study of these changes can provide invaluable insights into the choices and adaptive strategies that were utilized by both individuals and communities attempting to understand and redefine their place among society (see, e.g. Fitts, 2015).

Finally, more focused efforts should be made to study the ways in which both violent and non-violent processes of transformation impact vulnerable and historically marginalized socio-demographic groups, including women, children, the elderly, people with disabilities, and enslaved or unfree populations. Such groups might, for example, suffer from higher exposure to mortality resulting from illness, resource scarcity, or conflict, or be prevented from completing culturally prescribed rites of passage due to a breakdown of social institutions and traditions related to governance and kinship. Migration and transience, furthermore, are likely to have had a particularly formative influence on the social development and enculturation of children, who would grow up disconnected from the natal landscape and networks of their parents. The increased exposure of children to new traditions, materials, and interaction with out-groups may in turn have played a major role in driving processes of coalescence, especially when we consider the potential for children today to act as cultural mediators within transnational migratory contexts (see, e.g. Orellana, 2001; White et al., 2011). For enslaved groups, the inherent insecurity associated with life within a shatter zone may have presented both dangers and opportunities to renegotiate the conditions of their captivity. To date, discussions of the Mississippian shatter zone have yet to seriously consider the experiences of enslaved African groups, who would have faced the challenge of adapting to and establishing their own communities within a new and unfamiliar world undergoing rapid processes of cultural change (Bossy, 2014: 630631). In developing targeted studies of these and other communities, it is possible to nuance overall narratives of shatter zones in such a way that they speak to the experiences of multiple population groups occupying a variety of positions on the social spectrum.

\section{Final Remarks}

In sum, the purpose of this article was to highlight the potential for archaeological studies of shatter zones to facilitate our understanding of the ways in which populations respond to crisis and instability. Rather than perpetuating the dichotomous narratives of 'collapse' and 'resilience' that have crystallized around the discussion of large-scale processes of social upheaval and transformation in recent years, the study of shatter zones allows archaeologists to situate historical data within its wider geographical, socio-political, and cultural contexts, and to examine how these changes impacted the lives of populations both in the short-term and in the longue durée. The discussion above was informed by the seminal work of anthropologists and historians whose research has greatly augmented our knowledge of this concept and its application to the study of historic, transformative change (e.g. Ethridge, 2006, 2010; Ethridge \& Shuck-Hall, 2009). 
In making the arguments presented here, my intention was neither to simply add yet-another term to the theoretical vocabulary of the archaeological discipline, nor to present a complete and refined model for the study of shatter zones. Rather, my aim was to emphasize the potential for existing frameworks to provide new insights into important historical questions that are of relevance to contemporary society. In presenting and harnessing the panarchy and disentanglement models, the discussion above highlighted the benefits to be gained from adopting a multi-scalar approach to shatter zones. By treating the formation and development of a shatter zone as a process of dis- and re-entanglement, situated within the longer term context of adaptive change, it is possible to study both the proactive and reactive choices made by groups in response to changing conditions within their local and regional environments. This allows the results of local studies to contextualize, challenge, or affirm narratives based on those taking place at the regional and inter-regional levels.

Before closing, however, it is necessary once again to emphasize that the preliminary framework presented in this article is intentionally coarse - a heuristic tool to be further evaluated and refined as part of future studies. Given the extent of the previous literature that has sought to define and mobilize the concept of the shatter zone across disciplines, the broad scope of its application, and the need to contextualize this with existing archaeological, anthropological, and historical literature, it is impossible to fully explore the potential benefits and limitations of this approach within the remit of a single article. There is a clear need for the presentation of further case studies - drawn from a range of historical and cultural contexts - that would allow this discussion to be further refined and nuanced. With this goal in mind, it is hoped that others will seek to test and augment the arguments presented here and in doing so contribute to the development of a more holistic understanding of the ways in which instability and cultural transformation have shaped the human past.

Acknowledgements This article was inspired by a close reading of Robbie Ethridge and Sheri M. ShuckHalls' excellent edited work, Mapping the Mississippian Shatter Zone, which the author first encountered while working as a visiting scholar in the University of Pittsburgh's Center for Comparative Archaeology during the 2018-2019 academic year. The concept of the shatter zone offers an attractive theoretical framework for comparative research, and as such, this article represents a preliminary study intended to provide a basis for future work within my primary field of research - the study of migration, cultural interaction, conflict, and slavery in Viking-Age Scandinavia and early medieval Europe. I am most grateful to Prof. Neil Price, director of the Viking Phenomenon project at Uppsala University, for immediately realizing the potential for this work to inform several aspects of my current and planned research and for his support in this endeavour. A number of colleagues also took the time to read this manuscript. I am deeply indebted to Robbie Ethridge for her guidance and comments on the initial draft and to Jennifer Birch for her guidance on numerous aspects of Iroquoian archaeology. I am similarly grateful to Neil Price, Charlotte HedenstiernaJonson, John Ljungkvist, Kailin Hatlestad, Irene García Losquiño, Chris Nuttall, Henriette Rødland, Erika Weiberg, Marianne Hem Eriksen, Elizabeth Arkush, and Leszek Gardeła for discussion and comments and to the editors and four anonymous reviewers whose comments have greatly strengthened the final text. All remaining errors are my own.

Funding Open access funding provided by Uppsala University. The writing of this article was supported by a grant awarded by the Swedish Research Council to the Viking Phenomenon project (2015-00466). Publication costs for the Catawba Deerskin Map were generously provided by the Rydebergs Fond. 


\section{Declerations}

Conflict of Interest The author declares no competing interests.

Open Access This article is licensed under a Creative Commons Attribution 4.0 International License, which permits use, sharing, adaptation, distribution and reproduction in any medium or format, as long as you give appropriate credit to the original author(s) and the source, provide a link to the Creative Commons licence, and indicate if changes were made. The images or other third party material in this article are included in the article's Creative Commons licence, unless indicated otherwise in a credit line to the material. If material is not included in the article's Creative Commons licence and your intended use is not permitted by statutory regulation or exceeds the permitted use, you will need to obtain permission directly from the copyright holder. To view a copy of this licence, visit http://creativecommons.org/licenses/by/4.0/.

\section{References}

Adams, R. M. C. (1978). Strategies at maximization, stability, and resilience in Mesopotamian society, settlement, and agriculture. Proceedings of the American Philosophical Society, 122(5), 329-335.

Allen, C. R., Angeler, D. G., Garmestani, A. S., Gunderson, L. H., \& Holling, C. S. (2014). Panarchy: Theory and application. Ecosystems, 17(4), 578-589. https://doi.org/10.1007/s10021-013-9744-2.

Ambrose, S. H., Buikstra, J., \& Krueger, H. W. (2003). Status and gender differences in diet at Mound 72, Cahokia, revealed by isotopic analysis of bone. American Journal of Anthropological Archaeology, 22(3), 217-226. https://doi.org/10.1016/S0278-4165(03)00036-9.

Anderson, D. G. (1994). Savannah river chiefdoms: Political change in the late prehistoric South. The University of Alabama Press.

Anderson, D. G., \& Cook, R. (2017). The development of complex societies in eastern North America: The roles of feasting, famine, and fighting. In R. J. Chacon \& R. G. Mendoza (Eds.), Feast, famine, or fighting? Multiple pathways to social complexity (pp. 269-303). Springer International Publishing AG. https://doi.org/10.1007/978-3-319-48402-0_11.

Arlinghaus, J. T. (1988). The transformation of Afghan tribal society, tribal expansion, Mughal imperialism and the Roshaniya insurrection 1450-1600. PhD Dissertation: Duke University.

Arponen, V. P. J., Dörfler, W., Feeser, I., Grimm, S., Groß, D., Hinz, M., Knitter, D., Müller-Scheeßel, N., Ott, K., \& Ribeiro, A. (2019). Environmental determinism and archaeology. Understanding and evaluating determinism in research design. Archaeological Dialogues, 26(01), 1-9. https://doi.org/10.1017/ S1380203819000059.

Atalay, S. (2006). Indigenous archaeology as decolonizing practice. American Indian Quarterly, 30(3/4), 280310 .

Bartov, O., \& Weitz, E. D. (Eds.). (2013). Shatterzone of empires: Coexistence and violence in the German, Habsburg, Russian, and Ottoman borderlands. Indiana University Press.

Baum, R. M. (1999). Shrines of the Slave Trade. Diola Religion and Society in Precolonial Senegambia. Oxford University Press.

Beck, R. A. (2009). Catawba coalescence and the shattering of the Carolina Piedmont, 1540-1675. In R. Ethridge \& S. M. Shuck-Hall (Eds.), Mapping the Mississippian shatter zone. The colonial Indian slave trade and regional instability in the American South (pp. 115-141). University of Nebraska Press.

Beck, R. A. (2013). Chiefdoms, collapse, and coalescence in the early American South. Cambridge University Press.

Beck, R. A. (2016). Uniformity and diversity in Mississippian polity formation. In L. Amkreutx, F. Haack, D. Hoffman, \& I. van Wijk (Eds.), Something out of the ordinary: Interpreting diversity in the early Neolithic Linearbandkeramik and beyond (pp. 455-482). Cambridge Scholars Publishing.

Beck, R. A., Bolender, D. J., Brown, J. A., \& Earle, T. K. (2007). Eventful archaeology: The place of space in structural transformation. Current Anthropology, 48(6), 833-860. https://doi.org/10.1086/520974.

Bintliff, J. (2007). Emergent complexity in settlement systems and urban transformations. In E. Olhausen, U. Fellmeth, P. Guyot, \& H. Sonnabend (Eds.), Historische geographie der alten welt. Grundlagen, erträge, perspektiven. festgabe für Eckart Olshausen (pp. 43-82). Georg Olms Verlag.

Birch, J. (2010). Coalescence and conflict in Iroquoian Ontario. Archaeological Review from Cambridge, 25(1), 29-47. 
Birch, J. (2012). Coalescent communities: Settlement aggregation and social integration in Iroquoian Ontario. American Antiquity, 77(4), 646-670.

Birch, J. (2015). Current research on the historical development of northern Iroquoian societies. Journal of Archaeological Research, 23(3), 263-323. https://doi.org/10.1007/s10814-015-9082-3.

Birch, J. (2016). Geopolitics and dimensions of social complexity in ancestral Wendake c. A.D. 1450-1600. Ontario Archaeology, 96, 35-46.

Birch, J. (2020). Social institutions and the differential development of Northern Iroquoian confederacies. In D. M. Bondarenko (Ed.), The evolution of social institutions (pp. 419-435). Springer.

Birch, J., \& Hart, J. P. (2018). Social networks and northern Iroquoian confederacy dynamics. American Antiquity, 83(1), 13-33. https://doi.org/10.1017/aaq.2017.59.

Birch, J., \& Williamson, R. F. (2013). The Mantle Site: An archaeological history of an ancestral Wendat community. AltaMira.

Birch, J., Manning, S. W., Sanft, S., \& Conger, M. A. (2020). Refined radiocarbon chronologies for northern Iroquoian site sequences: Coalescence, conflict, and the reception of European goods. American Antiquity, 86(1), 61-89. https://doi.org/10.1017/aaq.2020.73.

Blackhawk, N. (2006). Violence over the land: Indians and empires in the early American west. Harvard University Press.

Blanton, D. B., Hensler, R., \& Snow, F. (2021). The case for a late Lamar polity on the lower Ocmulgee River in Georgia. Southeastern Archaeology. Advance online publication, 40(1), 48-73. https://doi.org/10. 1080/0734578X.2021.1873063.

Blewitt, R. (2016). Loss and discard of traditional ecological knowledge: Archaeology of Catawba foodways. MSc thesis, University of North Carolina at Chapel Hill.

Blitz, J. H. (2010). New perspectives in Mississippian archaeology. Journal of Archaeological Research, 18(1), 1-39. https://doi.org/10.1007/s10814-009-9033-y.

Blitz, J. H., \& Lorenz, K. G. (2006). The Chattahoochee chiefdoms. The University of Alabama Press.

Bossy, D. I. (2014). Shattering together, merging apart: Colonialism, violence, and the remaking of the Native south. The William and Mary Quarterly, 71(4), 611-631.

Bowne, E. E. (2009). "Caryinge awaye their corn and children": The effects of Westo slave raids on the Indians of the Lower South. In R. Ethridge \& S. M. Shuck-Hall (Eds.), Mapping the Mississippian shatter zone. The colonial Indian slave trade and regional instability in the American South (pp. 104-114). University of Nebraska Press.

Bradley, J. W. (2011). Re-visiting wampum and other seventeenth-century shell games. Archaeology of Eastern North America, 39, 25-51.

Bradtmöller, M., Grimm, S., \& Riel-Salvatore, J. (2017). Resilience theory in archaeological practice - An annotated review. Quaternary International, 446, 3-16. https://doi.org/10.1016/j.quaint.2016.10.002.

Bugge, P. (2002). 'Shatter zones': The creation and re-creation of Europe's East. In M. Spiering \& M. Wintle (Eds.), Ideas of Europe since 1914: The legacy of the First World War (pp. 47-68). Palgrave Macmillan.

Burmeister, S. (2000). Archaeology and migration: Approaches to an archaeological proof of migration. Current Anthropology, 41(4), 539-567. https://doi.org/10.1086/317383.

Butzer, K. W., \& Endfield, G. H. (2012). Critical perspectives on historical collapse. PNAS, 109(10), 36283631. https://doi.org/10.1073/pnas.1114772109.

Cable, J. S. (2020). Megadrought in the Carolinas. The archaeology of Mississippian collapse, abandonment, and coalescence. The University of Alabama Press.

Carter, W. H. (2008). Chains of consumption: The Iroquois and consumer goods, 1550-1800. PhD Thesis, Princeton University.

Chambers, I. (2013). A Cherokee origin for the 'Catawba' Deerskin Map (c. 1721). Imago Mundi, 65(2), 207216. https://doi.org/10.1080/03085694.2013.784564.

Clark, J. J. (2001). Tracking prehistoric migrations: Pueblo settlers among the Tonto Basin Hohokam. Anthropological Papers of the University of Arizona, 65, 14-22.

Clayton, S. C. (2016). After Teotihuacan: A view of collapse and reorganization from the southern basin of Mexico. American Anthropologist, 118(1), 104-120. https://doi.org/10.1111/aman.12522.

Cline, E. (2014). 1177 B.C.: The year civilization collapsed. Princeton University Press.

Cobb, C. R. (2003). Mississippian chiefdoms: How complex? Annual review of Anthropology, 32(1), 63-84.

Cohen, S. B. (1963). Geography and politics in a world divided. Oxford University Press.

Cohen, S. B. (2005). The Eurasian convergence zone: Gateway or shatterbelt? Eurasian Geography and Economics, 46(1), 1-22. https://doi.org/10.2747/1538-7216.46.1.1.

Cohen, S. B. (2015). Geopolitics: The geography of international relations. Rowman and Littlefield. 
Cohn, B. S. (1967). Regions subjective and objective: Their relation to the study of modern Indian history and society. In R. I. Crane (Ed.), Regions and regionalism in South Asian studies: an exploratory study (pp. 5-37). Duke University Press.

Cowgill, G. L. (2012). Concepts of collapse and regeneration in human history. In D. L. Nichols \& C. A. Pool (Eds.), The Oxford handbook of Mesoamerican archaeology (pp. 301-308). Oxford University Press. https://doi.org/10.1093/oxfordhb/9780195390933.013.0021.

Cranford, D. J. (2018). Catawba household variation in the late eighteenth century. PhD Thesis, University of North Carolina at Chapel Hill.

Danilovic, V. (2002). When the stakes are high: Deterrence and conflict among major powers. University of Michigan Press.

Dermarkar, S. (2019). Identity formation at the Keffer Iroquoian village: A relational network approach to communities of practice. PhD Thesis, University of Toronto.

Diakho, F., \& Gokee, C. (2020). Itato: Un village historique dans la Haute-Gambie. Nyame Akuma, 94, 17-25.

Diamond, J. (2005). Collapse: How societies choose to fail or succeed. Penguin.

Diaz, H., \& Trouet, V. (2014). Some perspectives on societal impacts of past climatic changes. History Compass, 12(2), 160-177. https://doi.org/10.1111/hic3.12140.

Drake, B. L. (2012). The influence of climatic change on the Late Bronze Age collapse and the Greek Dark Ages. Journal of Archaeological Science, 39(6), 1862-1870.

Driessen, J. (Ed.). (2018). An archaeology of forced migration: Crisis-induced mobility and the collapse of the $13^{\text {th }}$ c. BCE Eastern Mediterranean. Presses Universitaires de Louvain.

Dye, D. H. (2006). The transformation of Mississippian warfare: Four case studies from the Mid-South. In E. N. Arkush \& M. W. Allen (Eds.), The archaeology of warfare: Prehistories of raiding and conquest (pp. 101-147). University Press of Florida.

East, G. (1961). The concept and political status of the shatter zone. In N. J. G. Pounds (Ed.), Geographical essays on Eastern Europe (pp. 1-27). Indiana University.

Engelbrecht, W. (2003). Iroquoia: The development of a Native world. Syracuse University Press.

Erickson, C. L. (1999). Neo-environmental determinism and agrarian "collapse" in Andean prehistory. Antiquity, 73(281), 634-642. https://doi.org/10.1017/S0003598X00065236.

Ethridge, R. (2006). Creating the shatter zone. Indian slave traders and the collapse of the Southeastern chiefdoms. In T. J. Pluckhahn \& R. Ethridge (Eds.), Light on the path: The anthropology and history of the Southeastern Indians (pp. 207-218). The University of Alabama Press.

Ethridge, R. (2009a). Introduction: Mapping the Mississippian shatter zone. In R. Ethridge \& S. M. ShuckHall (Eds.), Mapping the Mississippian shatter zone. The colonial Indian slave trade and regional instability in the American South (pp. 1-62). University of Nebraska Press.

Ethridge, R. (2009b). The making of a militaristic slaving society: The Chickasaws and the colonial Indian slave trade. In A. Gallay (Ed.), Indian slavery in colonial America (pp. 250-276). University of Nebraska Press.

Ethridge, R. (2010). From Chicaza to Chickasaw. The European invasion and the transformation of the Mississippian world, 1540-1715. University of North Carolina Press.

Ethridge, R. (2020). Differential responses across the Southeast to European incursions. In E. A. Boudreaux III, M. Meyers, \& J. K. Johnson (Eds.), Contact, colonialism, and Native communities in the Southeastern United States (pp. 216-228). University of Florida Press.

Ethridge, R., \& Hudson, C. (1998). The early historic transformation of the Southeastern Indians. In C. E. Hill \& P. D. Beaver (Eds.), Cultural diversity in the U.S. South: Anthropological contributions to a region in transition (pp. 34-50). University of Georgia Press.

Ethridge, R., \& Shuck-Hall, S. M. (Eds.). (2009). Mapping the Mississippian shatter zone. The colonial Indian slave trade and regional instability in the American South. University of Nebraska Press.

Faulseit, R. K. (Ed.). (2016a). Beyond collapse: Archaeological perspectives on resilience, revitalization, and transformation in complex societies. Southern Illinois University Press.

Faulseit, R. K. (2016b). Collapse, resilience, and transformation in complex societies: Modelling trends and understanding diversity. In R. K. Faulseit (Ed.), Beyond collapse: Archaeological perspectives on resilience, revitalization, and transformation in complex societies (pp. 3-26). Southern Illinois University Press.

Feathers, J. K. (2006). Explaining shell-tempered pottery in prehistoric eastern North America. Journal of Archaeological Method and Theory, 13(2), 89-133.

Ferguson, R. B., \& Whitehead, N. L. (1992). The violent edge of empire. In R. B. Ferguson \& N. L. Whitehead (Eds.), War in the tribal zone. Expanding states and indigenous warfare (pp. 1-30). School of American Research Press.

Fitts, M. E. (2006). Mapping Catawba coalescence. North Carolina Archaeology, 55, 1-59. 
Fitts, M. E. (2015). The Indian slave trade and Catawba history. In L. W. Marshall (Ed.), The archaeology of slavery: A comparative approach to captivity and coercion (pp. 300-325). Southern Illinois University Press.

Fitts, M. E., \& Heath, C. L. (2009). "Indians refusing to carry burdens.” Understanding the success of Catawba political, military, and settlement strategies in Colonial Carolina. In R. Ethridge \& S. M. Shuck-Hall (Eds.), Mapping the Mississippian shatter zone. The colonial Indian slave trade and regional instability in the American South (pp. 142-162). University of Nebraska Press.

Flannery, K. V. (1972). The cultural evolution of civilizations. Annual Review of Ecology and Systematics, 3(1), 399-426. https://doi.org/10.1146/annurev.es.03.110172.002151.

Fox, W. (1985). Geopolitics and international relations. In C. E. Zoppo \& C. Zorgbibe (Eds.), On geopolitics: Classical and nuclear. NATO ASI Series. Series D: Behavioural and Social Sciences - No. 20. Matinus Nijhoff Publications.

Fox, W. A. (2009). Events as seen from the north: The Iroquois and colonial slavery. In R. Ethridge \& S. M. Shuck-Hall (Eds.), Mapping the Mississippian shatter zone. The colonial Indian slave trade and regional instability in the American South (pp. 63-80). University of Nebraska Press.

Galloway, P. (2009). Choctaws at the border of the shatter zone: Spheres of exchange and spheres of social value. In R. Ethridge \& S. M. Shuck-Hall (Eds.), Mapping the Mississippian shatter zone. The colonial Indian slave trade and regional instability in the American South (pp. 333-364). University of Nebraska Press.

Geobey, S., \& McGowan, K. A. (2019). Panarchy, ontological and epistemological phenomena, and the Plague. Ecology and Society, 24(4), 23. https://doi.org/10.5751/ES-11089-240423.

Gill, R. B. (2000). The great Maya droughts: Water, life, and death. University of New Mexico Press.

González-Ruibal, A. (2014). An Archaeology of resistance: Materiality and time in an African borderland. Rowman and Littlefield Publishers.

Gosden, C. (1999). The cultural biography of objects. World Archaeology, 31(2), 169-178.

Gunderson, L. H., \& Holling, C. S. (Eds.). (2002). Panarchy: Understanding transformations in human and natural systems. Island Press.

Hall Jr., J. M. (2009). Zamumo's gifts. Indian-European exchange in the colonial Southeast. University of Pennsylvania Press.

Hally, D. J. (2006). The nature of Mississippian regional systems. In T. H. Plukhahn \& R. Ethridge (Eds.), Light on the path: The anthropology and history of the Southeastern Indians (pp. 26-42). The University of Alabama Press.

Hally, D. J., \& Smith, M. T. (2011). Sixteenth-century mechanisms of exchange. Journal of Global Initiatives, 5(1), 53-65.

Hart, J. P., Shafle, T., Birch, J., Dermarkar, S., \& Williamson, R. F. (2016). Nation building and social signaling in southern Ontario: A.D. 1350-1650. PLoS ONE, 11(5), e0156178. https://doi.org/10.1371/ journal.pone.0156178.

Hartshorne, R. (1941). The politico-geographic pattern of the world. The Annals of the American Academy of Political and Social Science, 218(1), 45-57.

Hauser, M. W., \& Armstrong, D. V. (2012). The archaeology of not being governed: A counterpoint to a history of settlement of two colonies in the eastern Caribbean. Journal of Social Archaeology, 12(3), 310333. https://doi.org/10.1177/1469605312443940.

Hawkins, A. L., Malleau, K., \& Elliott, D. (2018). A consideration of participants in Huron-Wendat subsistence strategies across the pre-contact and early colonization periods. Journal of Archaeological Science: Reports, 20, 873-880. https://doi.org/10.1016/j.jasrep.2017.10.024.

Heather, P. (2010). Empires and barbarians: The fall of Rome and the birth of Europe. Oxford University Press.

Hensel, P. R., \& Diehl, P. F. (1994). Testing empirical propositions about shatterbelts, 1945-76. Political Geography, 13(1), 33-51. https://doi.org/10.1016/0962-6298(94)90009-4.

Hill, M. C. (1996). Protohistoric aborigines in West-Central Alabama: Correlations to early European contact. In B. J. Baker \& L. Kealhofer (Eds.), Bioarchaeology of Native American adaptation in the Spanish borderlands (pp. 17-37). University Press of Florida.

Hodder, I. (2012). Entangled. An archaeology of the relationships between humans and things. WileyBlackwell.

Hoffman, G. W. (1952). The shatter-belt in relation to the east-west conflict. Journal of Geography, 51(7), 265-275. https://doi.org/10.1080/00221345208982758.

Holland-Lulewicz, J., Thompson, V. D., Wettstaed, J., \& Williams, M. (2020). Enduring traditions and the (im)materiality of early colonial encounters in the Southeastern United States. American Antiquity, 85(4), 694-714. https://doi.org/10.1017/aaq.2020.40. 
Holling, C. S. (1973). Resilience and stability of ecological systems. Annual Review of Ecology and Systematics, 4(1), 1-23. https://doi.org/10.1146/annurev.es.04.110173.000245.

Holling, C. S. (2001). Understanding the complexity of economic, ecological, and social systems. Ecosystems, 4(5), 390-405. https://doi.org/10.1007/s10021-001-0101-5.

Holling, C. S., \& Gunderson, L. H. (2002). Resilience and adaptive cycles. In L. H. Gunderson \& C. S. Holling (Eds.), Panarchy: Understanding transformations in human and natural systems (pp. 25-62). Island Press.

Holling, C. S., Gunderson, L. H., \& Peterson, G. D. (2002). Sustainability and panarchies. In L. H. Gunderson \& C. S. Holling (Eds.), Panarchy: Understanding transformations in human and natural systems (pp. $63-$ 102). Island Press.

Hoover, K. C., \& Hudson, M. J. (2016). Resilience in prehistoric persistent hunter-gatherers in northwest Kyushu, Japan as assessed by population health and archaeological evidence. Quaternary International, 405, 22-33. https://doi.org/10.1016/j.quaint.2015.10.047.

Hudson, C. (2002). Introduction. In R. Ethridge \& C. Hudson (Eds.), The transformation of the Southeastern Indians 1540-1715 (pp. xi-Xxxix). University Press of Mississippi.

Iannone, G. (2002). Annales history and the ancient Maya state: Some observations on the "Dynamic Model". American Anthropologist, 104(1), 68-78.

Iannone, G. (2016). Release and reorganization in the tropics: A comparative perspective. In R. K. Faulseit (Ed.), Beyond collapse: Archaeological perspectives on resilience, revitalization, and transformation in complex societies (pp. 179-212). Southern Illinois University Press.

Izdebski, A., Mordechai, L., \& White, S. (2018). The social burden of resilience: A historical perspective. Human Ecology, 46(3), 291-303. https://doi.org/10.1007/s10745-018-0002-2.

Jackes, M. (2008). The mid seventeenth century collapse of Iroquoian Ontario: Examining the last burial place of the Neutral nation. In I. Séguy, L. Buchet, \& C. Rigeade (Eds.), Vers une anthropologie des catastrophes (pp. 347-373). INED.

James, S. (2018). Warriors, war, and weapons; or arms, the armed, and armed violence. In C. Haselgrove, K. Rebay-Salisbury, \& P. S. Wells (Eds.), The Oxford handbook of the European Iron Age. https://doi.org/ 10.1093/oxfordhb/9780199696826.013.26 Accessed 10 $10^{\text {th }}$ October 2019.

Jenkins, N. J. (2009). Tracing the origins of the early Creeks. In R. Ethridge \& S. M. Shuck-Hall (Eds.), Mapping the Mississippian shatter zone. The colonial Indian slave trade and regional instability in the American South (pp. 188-249). University of Nebraska Press.

Jennings, M. H. (2009). Violence in a shattered world. In R. Ethridge \& S. M. Shuck-Hall (Eds.), Mapping the Mississippian shatter zone. The colonial Indian slave trade and regional instability in the American South (pp. 272-294). University of Nebraska Press.

Jeter, M. D. (2002). From prehistory through protohistory to ethnohistory in and near the Northern Lower Mississippi Valley. In R. Ethridge \& C. Hudson (Eds.), The transformation of the Southeastern Indians, 1540-1760 (pp. 177-224). University Press of Mississippi.

Jeter, M. D. (2009). Shatter zone shock waves along the Lower Mississippi. In R. Ethridge \& S. M. ShuckHall (Eds.), Mapping the Mississippian shatter zone. The colonial Indian slave trade and regional instability in the American South (pp. 365-387). University of Nebraska Press.

Johnson, J. K., O’Hear, J. W., Ethridge, R., Lieb, B. R., Scott, S. L., \& Jackson, H. E. (2008). Measuring Chickasaw adaptation on the western frontier of the colonial South: A correlation of documentary and archaeological data. Southeastern Archaeology, 27(1), 1-30.

Jordan, K. A. (2013). Incorporation and colonization: Postcolumbian Iroquois satellite communities and processes of indigenous autonomy. American Anthropologist, 115(1), 29-43. https://doi.org/10.1111/j. 1548-1433.2012.01533.x.

Jordan, K. A. (2018). Markers of difference or makers of difference? Atypical practices at Haudenosaunee (Iroquois) satellite sites, ca. 1650-1700. Historical Archaeology, 52(1), 12-29. https://doi.org/10.1007/ s41636-017-0079-2.

Kelton, P. (2009). Shattered and infected: Epidemics and the origins of the Yamasee War, 1696-1715. In R. Ethridge \& S. M. Shuck-Hall (Eds.), Mapping the Mississippian shatter zone. The colonial Indian slave trade and regional instability in the American South (pp. 312-332). University of Nebraska Press.

Kowalewski, S. A. (2006). Coalescent societies. In T. J. Pluckhahn \& R. Ethridge (Eds.), Light on the path: The anthropology and history of the Southeastern Indians (pp. 94-122). The University of Alabama Press.

Kroot, M. V., Gokee, C., \& Machiels, C. (2019). Yoro Moussou: A Malinké fortified site in southeastern Senegal. Nyame Akuma, 91, 23-29.

Labelle, K. M. (2009). "They only spoke in sighs": The loss of leaders and life in Wendake, 1633-1639. Journal of Historical Biography, 6(Autumn 2009), 1-33. 
Larsen, C. S., Griffin, M. C., Hutchinson, D. L., Noble, V. E., Norr, L., Pastor, R. F., Ruff, C. B., Russell, K. F., Schoeninger, M. J., Schultz, M., Simpson, S. W., \& Teaford, M. F. (2001). Frontiers of contact: Bioarchaeology of Spanish Florida. Journal of World Prehistory, 15(1), 69-123.

Legg, J. B., Blanton, D. B., Cobb, C. R., Smith, S. D., Lieb, B. R., \& Boudreaux III, E. A. (2019). An appraisal of the indigenous acquisition of Contact-Era European metal objects in southeastern North America. International Journal of Historical Archaeology, 23(1), 81-102. https://doi.org/10.1007/ s10761-018-0458-1.

Little, K. J. (2008). European artifact chronology and impacts of Spanish contact in the sixteenth-century Coosa valley. PhD Thesis, The University of Alabama.

Lulewicz, J. (2019). The social networks and structural variation of Mississippian sociopolitics in the southeastern United States. PNAS, 116(14), 6707-6712. https://doi.org/10.1073/pnas.1818346116.

Lulewicz, J., \& Coker, A. B. (2018). The structure of the Mississippian world: A social network approach to the organization of sociopolitical interactions. Journal of Anthropological Archaeology, 50, 113-127. https://doi.org/10.1016/j.jaa.2018.04.003.

Lutz, D. S. (1998). The Iroquois Confederation constitution: An analysis. Publius, 28(2), 99-127.

Lynch, J. (1985). The Iroquois Confederacy and the adoption and administration of non-Iroquoian individuals and groups prior to 1756. Man in the Northeast, 40, 83-99.

Mackinder, H. J. (1904). The geographical pivot of history. The Geographical Journal, 23(4), 421-437.

Mackinder, H. J. (1919). Democratic ideals and reality: A study of the politics of reconstruction. Henry Holt and Company., 23(4), 421. https://doi.org/10.2307/1775498.

Mahan, A. T. (1900). The problem of Asia and its effect upon international policies. Little, Brown, and Company.

Marcoux, J. B. (2010). Pox, empire, shackles, and hides: The Townsend Site, 1670-1715. The University of Alabama Press.

Marcus, J. (1993). Ancient Maya political organization. In J. Sabloff \& J. Henderson (Eds.), Lowland Maya civilization of the eighth century $A D$ (pp. 111-184). Dumbarton Oaks.

Marcus, J. (1998). The peaks and valleys of ancient states: An extension of the Dynamic Model. In G. M. Feinman \& J. Marcus (Eds.), Archaic states (pp. 59-94). SAR Press.

Marcus, J. (2008). The archaeological evidence for social evolution. Annual Review of Anthropology, 37(1), 251-266. https://doi.org/10.1146/annurev.anthro.37.081407.085246.

Marcus, J. (2012). Maya political cycling and the story of the Kaan polity. In G. E. Braswell (Ed.), The ancient Maya of Mexico: reinterpreting the past of the northern Maya Lowlands (pp. 88-116). Equinox Press.

Marcus, J., \& Flannery, K. V. (2003). An introduction to the Late Postclassic. In K. V. Flannery \& J. Marcus (Eds.), The cloud people: Divergent evolution of the Zapotec and Mixtec civilisations (pp. 217-226). Percheron Press.

Marston, J. M. (2011). Archaeological markers of agricultural risk management. Journal of Anthropological Archaeology, 30(2), 190-205. https://doi.org/10.1016/j.jaa.2011.01.002.

Martin, D. L. (2016). Hard times in dry lands: Making meaning of violence in the ancient Southwest. Journal of Anthropological Research, 72(1), 1-23. https://doi.org/10.1086/685281.

Martin, D. L., Harrod, R. P., \& Fields, M. (2010). Beaten down and worked to the bone: Bioarchaeological investigations of women and violence in the ancient Southwest. Landscapes of Violence, 1(1). http:// scholarworks.umass.edu/lov/vol1/iss1/3. Accessed 5 Apr 2021.

Matthee, R. (2015). Relations between the center and the periphery in Safavid Iran: The western borderlands v. the eastern frontier zone. The Historian, 77(3), 431-463. https://doi.org/10.1111/hisn.12068.

McAnany, P. A., \& Yoffee, N. (Eds.). (2010). Questioning collapse: Resilience, ecological vulnerability, and the aftermath of empire. Cambridge University Press.

Mehta, J. M. (2019). Mound building and summit architecture at the Carson site, a Mississippian mound center in the southeastern United States. North American Archaeologist, 40(2), 67-98.

Melton, M. (2018). Cropping in an age of captive taking: Exploring evidence for uncertainty and food insecurity in the seventeenth-century North Carolina Piedmont. American Antiquity, 83(2), 204-233. https://doi.org/10.1017/aaq.2017.63.

Mesquida, C. G., \& Wiener, N. I. (1996). Human collective aggression: A behavioural ecology perspective. Ethnology and Sociobiology, 17(4), 247-262. https://doi.org/10.1016/0162-3095(96)00035-0.

Mesquida, C. G., \& Wiener, N. I. (1999). Male age composition and severity of conflicts. Politics and the Life Sciences, 18(2), 181-189. https://doi.org/10.1017/S0730938400021158.

Meyer, C., Lohr, C., Gronenborn, D., \& Alt, K. W. (2015). The massacre mass grave of SchöneckKilianstädten reveals new insights into collective violence in Early Neolithic Central Europe. Proceedings of the National Academy of Sciences of the United States of America, 112(36), 1121711222. https://doi.org/10.1073/pnas.1504365112. 
Meyer, C., Kürbis, O., Dresely, V., \& Alt, K. W. (2018). Patterns of collective violence in the early Neolithic in Central Europe. In A. Dolfini, R. J. Crellin, C. Horn, \& M. Uckelmann (Eds.), Prehistoric warfare and violence. Quantitative and qualitative approaches (pg. 21-38). Springer.

Meyers, M. (2009). From refugees to slave traders: The transformation of the Westo Indians. In: R. Ethridge, \& S. M. Shuck-Hall (Eds.), Mapping the Mississippian shatter zone. The colonial Indian slave trade and regional instability in the American South (pg. 81-103). University of Nebraska Press.

Meyers, M. (2016). Political economy and craft production before and after the collapse of Mississippian chiefdoms. In R. K. Faulseit (Ed.), Beyond collapse: Archaeological perspectives on resilience, revitalization, and transformation in complex societies (pp. 380-403). Southern Illinois University Press.

Michelaki, K. (2007). More than meets the eye: Reconsidering variability in Iroquoian ceramics. Canadian Journal of Archaeology, 31, 143-170.

Middleton, G. D. (2012). Nothing lasts forever: Environmental discourses on the collapse of past societies. Journal of Archaeological Research, 20(3), 257-307. https://doi.org/10.1007/s10814-011-9054-1.

Middleton, G. D. (2017). The show must go on. Collapse, resilience, and transformation in $21^{\text {st }}$-century archaeology. Reviews in Anthropology, 46(2-3), 78-105. https://doi.org/10.1080/00938157.2017. 1343025 .

Miller, J. (1997). Mississippian political economy. Plenum Press.

Milner, G. R. (1980). Epidemic disease in the postcontact southeast: A reappraisal. Midcontinental Journal of Archaeology, 5(1), 39-56.

Morley Davies, A. (1907). Contributions to geography in the geological literature of 1906. The Geographical Teacher, 4(1), 42-44.

Nelson, T. C. 2020. Material evidence for early coalescence: The Hightower village site (1TA150) in the Coosa river valley. $\mathrm{PhD}$ Thesis, The University of Alabama.

Nelson, M. C., Hegmon, M., Kulow, S., \& Gust Schollmeyer, K. (2006). Archaeological perspectives on reorganization: A case study from the Mimbres region of the U.S. Southwest. American Antiquity, 71(3), 403-432. https://doi.org/10.1017/S0002731600039755.

Nelson, M. C., Ingram, S. E., Dugmore, A. J., Streeter, R., Peeples, M. A., McGovern, T. H., Hegmon, M., Arneborg, J., Kintigh, K. W., Brewington, S., Spielmann, K. A., Simpson, I. A., Strawhacker, C., Comeau, L. E. L., Torvinen, A., Madsen, C. K., Hambrecht, G., \& Smiarowski, K. (2015). Climate challenges, vulnerabilities, and food security. PNAS, 113(2), 298-303. https://doi.org/10.1073/pnas. 1506494113.

Orellana, M. (2001). The work kids do: Mexican and Central American immigrant children's contributions to households, schools and community in California. Harvard Educational Review, 7(3), 366-389. https:// doi.org/10.17763/haer.71.3.52320g7n21922hw4.

Parkinson, W. A., \& Galaty, M. L. (2007). Secondary states in perspective: An integrated approach to state formation in the prehistoric Aegean. American Anthropologist, 109(1), 113-129.

Peña, E. S. (2001). The role of wampum production at the Albany almshouse. International Journal of Historical Archaeology, 5(2), 155-174.

Peterson, N., \& Broad, K. (2016). Climate and weather discourse in anthropology: From determinism to uncertain futures. In S. A. Crate \& M. Nuttall (Eds.), Anthropology and climate change: From encounters to actions (pp. 70-86). Routledge.

Piker, J. (2004). Okfuskee: A Creek Indian town in colonial America. Harvard University Press.

Price, N. (2020). Children of Ash and Elm: A history of the Vikings. Basic Books.

Price, N., \& Gräslund, B. (2015). Excavating the Fimbulwinter? Archaeology, geomythology and the climate event(s) of AD 536. In F. Riede (Ed.), Volcanic eruptions and human vulnerability in traditional societies past and present (pp. 109-132). Aarhus.

Ramenofsky, A. E., \& Galloway, P. (1997). Disease and the Soto Entrada. In P. Galloway (Ed.), The Hernando De Soto expedition: History, historiography and "discovery" in the Southeast (pp. 259279). University of Nebraska Press.

Redfern, R. (2020). Iron Age 'predatory landscapes': A bioarchaeological and funerary exploration of captivity and enslavement in Britain. Cambridge Archaeological Journal, 30(4), 531-554. https://doi. org/10.1017/S0959774320000062.

Redman, C. L. (2005). Resilience theory in archaeology. American Anthropologist, 107(1), 70-77.

Redman, C. L. (2012). Global environmental change, resilience, and sustainable outcomes. In J. Cooper \& P. Sheets (Eds.), Surviving sudden environmental change. Answers from archaeology (pp. 237-244). University Press of Colorado.

Reilly, D. (2000). Shatterbelts and conflict behaviour: The effect of globalisation on "high risk" states. Geopolitics, 5(3), 48-77. https://doi.org/10.1080/14650040008407691.

Renfrew, C. (1984). Approaches to social archaeology. Harvard University Press. 
Richter, D. K. (1983). War and culture: The Iroquois experience. The William and Mary Quarterly, 40(4), 528-599. https://doi.org/10.2307/1921807.

Richter, D. K. (1992). The ordeal of the longhouse: The peoples of the Iroquoian League in the era of European colonization. University of North Carolina Press.

Rodning, C. B. (2002). William Bartram and the archaeology of the Appalachian Summit. In C. B. Wesson \& M. A. Rees (Eds.), Between contact and colonies (pp. 67-89). The University of Alabama Press.

Rodning, C. B. (2009). Mounds, myths, and Cherokee townhouses in southwestern North Carolina. American Antiquity, 74(4), 627-663. https://doi.org/10.1017/S000273160004899X.

Rogers, J. D. (2017). Dynamic trajectories, adaptive cycles, and complexity in culture change. Journal of Archaeological Method and Theory, 24(4), 1326-1355. https://doi.org/10.1007/s10816-017-9314-6.

Sabo III, G., Hilliard, J. E., Walker, L. C., Lockhart, J. J., Early, A. M., \& Wiewel, R. I. F. (2020). Indigenous responses to Europeans on the far reaches of the Mississippian shatter zone. In E. A. Boudreaux III, M. Meyers, \& J. K. Johnson (Eds.), Contact, colonialism, and Native communities in the Southeastern United States (pp. 16-34). University of Florida Press.

Saltini Semerari, G. (2017). Towards an archaeology of disentanglement. Journal of Archaeological Method and Theory, 24(2), 542-578. https://doi.org/10.1007/s10816-016-9277-z.

Saunders, R. (2017). Revitalization movements in the prehistoric Southeast? An example from the Irene Site. In G. A. Waselkov \& M. T. Smith (Eds.), Forging Southern identities: Social archaeology, ethnohistory, and folklore of the Mississippian to early historic South (pp. 41-61). The University of Alabama Press.

Scarry, J. F. (1994). The Apalachee chiefdom: A Mississippian society on the fringe of the Mississippian world. In C. M. Hudson \& C. Chaves (Eds.), The forgotten centuries: Indians and Europeans in the American South, 1521-1704 (pp. 156-178). University of Georgia Press.

Scarry, J. F. (1996). Stability and change in the Apalchee chiefdom. In J. F. Scarry (Ed.), Political structure and change in the prehistoric Southeastern United States (pp. 192-227). University of Florida Press.

Schoon, M., Fabricius, C., Anderies, J., \& Nelson, M. (2011). Synthesis: Vulnerability, traps, and transformations-long-term perspectives from archaeology. Ecology and Society, 16(2). http://www. ecologyandsociety.org/vol16/iss2/art24/. Accessed 5 Apr 2021.

Schwartz, G. M. (2006). From collapse to regeneration. In G. M. Schwartz \& J. J. Nichols (Eds.), After collapse: The regeneration of complex societies (pp. 3-17). University of Arizona Press.

Schwartz, G. M., \& Nichols, J. J. (Eds.). (2006). After collapse: The regeneration of complex societies. University of Arizona Press.

Scott, J. (2009). The art of not being governed: An anarchist history of upland Southeast Asia. Yale University Press.

Sedig, J. (2016). The decline and reorganization of Southwestern complexity: Using resilience theory to examine the collapse of Chaco Canyon. In R. K. Faulseit (Ed.), Beyond collapse: Archaeological perspectives on resilience, revitalization, and transformation in complex societies (pp. 262-287). Southern Illinois University Press.

Sheets, P. (2012). Responses to explosive volcanic eruptions by small to complex societies in ancient Mexico and Central America. In J. Cooper \& P. Sheets (Eds.), Surviving sudden environmental change. Answers from archaeology (pp. 43-63). University Press of Colorado.

Shefveland, K. M. (2016). Anglo-Native Virginia: Trade, conversion, and Indian slavery in the Old Dominion, 1646-1722. University of Georgia Press.

Sherwood, S. C., \& Kidder, T. R. (2011). The DaVincis of dirt: Geoarchaeological perspective on Native American mound building in the Mississippi River basin. Journal of Anthropological Archaeology, 30(1), 69-87. https://doi.org/10.1016/j.jaa.2010.11.001.

Shuck-Hall, S. M. (2009). Alabama and Coushatta diaspora and coalescence in the Mississippian shatter zone. In R. Ethridge \& S. M. Shuck-Hall (Eds.), Mapping the Mississippian shatter zone. The colonial Indian slave trade and regional instability in the American South (pp. 250-271). University of Nebraska Press.

Silliman, S. W. (2005). Culture contact or colonialism? Challenges in the archaeology of Native America. American Antiquity, 70(1), 55-74. https://doi.org/10.2307/40035268.

Silliman, S. W. (2009). Between the long durée and the short purée: Postcolonial archaeologies of indigenous history in colonial North America. In M. Oland, S. M. Hart, \& L. Frink (Eds.), Decolonizing Indigenous histories. Exploring prehistoric/colonial transitions in archaeology (pp. 86-112). The University of Arizona Press.

Simon, H. A. (1965). The architecture of complexity. In L. von Bertalanffy \& A. Rapoport (Eds.), General systems: Yearbook of the Society for General Systems Research (pp. 63-76). Society for General Systems Research. 
Smith, M. T. (1994). Aboriginal depopulation in the postcontact Southeast. In C. Hudson \& C. C. Tesser (Eds.), The forgotten centuries: Indians and Europeans in the American South, 1521-1704 (pp. 257275). University of Georgia Press.

Smith, M. T. (2000). Coosa: The rise and fall of a Mississippian chiefdom. University Press of Florida.

Snow, D. R. (1994). The Iroquois. Blackwell Publishers.

Snyder, C. (2010). Slavery in Indian country: The changing face of captivity in early America. Harvard University Press.

Stark, M. T. (2006). From Funan to Angkor: collapse and regeneration in ancient Cambodia. In G. M. Schwartz \& J. J. Nichols (Eds.), After collapse: The regeneration of complex societies (pp. 144-167). University of Arizona Press.

Starna, W. A., \& Watkins, R. (1991). Northern Iroquoian slavery. Ethnohistory, 1, 34-57.

Stauffer, J. G. (2020). Vestiges of the Braden Corridor. In C. H. McNutt \& R. M. Parish (Eds.), Cahokia in context: Hegemony and diaspora (pp. 369-390). University of Florida press.

Stoddart, S. (2010). Boundaries of the state in time and space: Transitions and tipping points. Social Evolution and History, 9, 28-52.

Struever, S. (1964). The Hopewell Interaction Sphere in riverine-Western Great Lakes culture history. In J. R. Caldwell \& R. L. Hall (Eds.), Hopewellian studies (Vol. 12, pp. 85-106). Illinois State Museum.

Sublett, A. J., \& Wray, C. F. (1970). Some examples of accidental and deliberate human modification in the Northeast. The Bulletin. Journal of the New York State Archaeological Association, 50, 14-26.

Tainter, J. A. (1988). The collapse of complex societies. Cambridge University Press.

Teschler-Nicola, M. (2012). The early Neolithic site Asparn/Schletz (Lower Austria): anthropological evidence of interpersonal violence. In R. Schulting \& L. Fibiger (Eds.), Sticks, stones, and broken bones (pp. 101-120). Oxford University Press.

Thompson, A. R., Hedman, K. M., \& Slater, P. A. (2015). New dental and isotopic evidence of biological distance and place of origin for mass burial groups at Cahokia's Mound 72. American Journal of Physical Anthropology, 158(2), 341-357. https://doi.org/10.1002/ajpa.22791.

Torvinen, A., Hegmon, M., Kinzig, A. P., Nelson, M. C., Peeples, M. A., Strawhacker, C., Shollmeyer, K. G., \& Stanek, L. (2016). Transformation without collapse: Two cases from the U.S. Southwest. In R. K. Faulseit (Ed.), Beyond collapse: Archaeological perspectives on resilience, revitalization, and transformation in complex societies (pp. 262-286). Southern Illinois University Press.

Trigger, B. (1987). The children of Aataentsic: A history of the Huron people to 1660. McGill-Queen's University Press.

Turner, B. L., \& Sabloff, J. A. (2012). Classic Period collapse of the Central Maya Lowlands: insights about human-environment relationships for sustainability. Proceedings of the National Academy of Sciences of the United States of America, 109(35), 13908-13914. https://doi.org/10.1073/pnas.1210106109.

VanDerwarker, A. M., Marcoux, J. B., \& Hollenbach, K. D. (2013). Farming and foraging at the crossroads: The consequences of Cherokee and European interaction through the late eighteenth century. American Antiquity, 78(1), 68-88.

Walker, B., Gunderson, L., Kinzig, A., Folke, C., Carpenter, S., \& Schultz, L. (2006). Handful of heuristics and some propositions for understanding resilience in social-ecological systems. Ecology and Society, 11(1), 13.

Ward, H. T., \& Davis Jr., R. P. S. (1993). Indian communities on the North Carolina Piedmont A.D. 1000 to 1700. The University of North Carolina at Chapel Hill.

Warren, S., \& Noe, R. (2009). "The greatest travellers in America": Shawnee survival in the shatter zone. In R. Ethridge \& S. M. Shuck-Hall (Eds.), Mapping the Mississippian shatter zone. The colonial Indian slave trade and regional instability in the American South (pp. 163-187). University of Nebraska Press.

Warrick, G. A. (2008). A population history of the Huron-Petun, AD 500-1650. Cambridge University Press.

Waselkov, G. A., \& Dumas, A. A. (2009). Archaeological clues to a Seventeenth-century pan-Southeastern revitalization movement (p. 2009). Alabama: Paper presented at the Southeastern Archaeological Conference Mobile.

Weiberg, E. (2012). What can resilience theory do for (Aegean) archaeology? In M. Burström \& F. Fahlander (Eds.), Matters of scale: Processes and courses of events in archaeology and cultural history (pp. 146165). Stockholm University.

Weiberg, E., \& Finné, M. (2013). Mind or matter? People-environment interactions and the demise of Early Helladic II society in the Northeastern Peloponnese. American Journal of Archaeology, 117(1), 1-31. https://doi.org/10.3764/aja.117.1.0001.

Weiberg, E., \& Finné, M. (2018). Resilience and persistence of ancient societies in the face of climate change: a case study from Late bronze Age Peloponnese. World Archaeology, 50(4), 584-602. https://doi.org/10. 1080/00438243.2018.1515035. 
Weiss, H. (Ed.). (2017). Megadrought and collapse: From early agriculture to Angkor. Oxford University Press.

White, R. (1991). The middle ground: Indians, empires, and republics in the Great Lakes region, 1650-1815. Cambridge University Press.

White, A., Ní, L., Tyrell, N. C., \& Carpena-Méndez, F. (2011). Children's roles in transnational migration. Journal of Ethnic and Migration Studies, 37(8), 1159-1170. https://doi.org/10.1080/1369183X.2011. 590635.

Williamson, R. (2007). "Otinontsiskiaj ondaon" ("the house of cut-off heads"). The history and archaeology of Northern Iroquoian trophy taking. In R. J. Chacon \& D. H. Dye (Eds.), The taking and displaying of human body parts as trophies by Amerindians (pp. 190-221). Springer.

Winkler, L. A., Larsen, C. S., Thompson, V. D., Sciulli, P. W., Hutchinson, D. L., Thomas, D. H., Blair, E. H., \& Sanger, M. C. (2017). The social structuring of biological stress in contact-era Spanish Florida. A bioarchaeological case study from Santa Catalina de Gaule, St. Catherines Island, Georgia. In M. S. Murphy \& H. D. Klaus (Eds.), Colonized bodies, worlds transformed. Towards a global bioarchaeology of contact and colonialism (pp. 129-164). University Press of Florida.

Wolf, E. R. (1997). Europe and the people without history. University of California Press.

Worth, J. E. (2002). Spanish missions and the persistence of chiefly power. In R. Ethridge \& C. Hudson (Eds.), The transformation of the Southeastern Indians, 1540-1760 (pp. 39-64). University Press of Mississippi.

Worth, J. E. (2009). Razing Florida: The Indian slave trade and the devastation of Spanish Florida, 1696-1715. In R. Ethridge \& S. M. Shuck-Hall (Eds.), Mapping the Mississippian shatter zone. The colonial Indian slave trade and regional instability in the American South (pp. 295-311). University of Nebraska Press.

Wray, C. F., Sempowski, M. L., Saunders, L. P., \& Cervone, G. (1987). The Adams and Culbertson sites. Rochester Museum and Science Center.

Yoffee, N., \& Cowgill, G. L. (Eds.). (1988). The collapse of ancient states and civilizations. University of Arizona Press.

Zimmerman, L. (1997). The Crow Creek massacre, archaeology and prehistoric Plains warfare in contemporary perspective. In J. Carman (Ed.), Material harm: Archaeological studies of war and violence (pp. 7595). Cruithne Press.

Publisher's Note Springer Nature remains neutral with regard to jurisdictional claims in published maps and institutional affiliations. 